International Journal of Educational Studies

ISSN: 2641-533X

Vol. 1, No. 2, pp. 26-70

2018

DOI: $10.53935 / 2641-533 x . v 1 i 2.19$

(C) 2018 by the authors; licensee Academic Publishing Group

\title{
Education Training and Human Rights of the Prisoners in Bangladesh
}

\author{
-Abdul Hamid: Department of Law, University of Rajshahi, Bangladesh.
}

Hosneara Begum: Department of Law, University of Rajshahi, Bangladesh.

ABSTRACT: Every human being is entitled to the inherent rights of nature. They are entitled to possess these rights subject to the provisions of the law applied to the land. The concept of society is meaningless without the presence of these inherent rights of a human being. The term human rights are being collectively used to mean those legal claims which are related to mankind. And such type of universal rights of human beings grew in mankind from the very ancient time. These rights are so inherent that without these a man cannot think of living with due dignity. Human rights therefore represent minimal moral standards for human society. Every country has its own criminal justice delivery system under which certain acts or omission is regarded as crime and sufficient sanctioning measures are there. An individual who is charged with the commission of a crime is regarded as an accused. Accused who is arrested and forwarded for criminal trial is called a prisoner. A prisoner has the right to defend himself against the charges brought against him/her by every facility ensured by the law. Many efforts in international and in municipal arena as well are found for the promotion and protection of the rights of public in general and of the prisoners in particular. For this purpose some important and remarkable human rights instruments like the Universal Declaration of Human Rights, 1948, the International Covenant on Civil and Political Rights, 1966, the United Nations Standard Minimum Rules for the Treatment of Prisoners, 1957, the United Nations Draft Body of Principles for the Protection of All Persons Under Any form of Detention or Imprisonment, 1988 and in various domestic legislations. However, our present judicial system is surrounded by thousands of problems. Throughout the whole country paucity of courts or judges are common feature of our judicial system. Moreover, the unhygienic environment in the prisons caused by the overcrowding of prisoners need to be examined for the protection of the rights of the prisoners. Protection of the rights and interests of the prisoners as well as there psychological and economic assistance is vitally important for the fair implementation of criminal laws and also for gaining public confidence in criminal justice system. Therefore, this study seeks to explore those particular factors that impair the criminal justice system, which is essentially important for the protection of the rights of the prisoners. This study also seeks to correlate international and national protection of human rights which are applicable to the prisoners' criminal proceedings in particular. The condition of the prisoners in the jail custody of Bangladesh has been set forth in detail and a comparison with the different international and domestic instruments are dealt with in this study. The purpose of this study is to show and examine the legal position of the prisoners and recognition of their rights including education and training of the prisoners within the purview of international as well as municipal law of Bangladesh. This study has also been reflected on human rights situation with regard to the prisoners in Bangladesh. Another issue is to be taken into consideration that, a human being of any age may commit crime. During the period when an accused or a convict remains within the walls of the prison cells usually can not take formal education of the land and there is a high apprehension that after his or her release he/she may be involved again in crime immediately. Therefore, if these persons can achieve necessary education and training during their stay in prison they can lead a better life after release from jail custody by utilizing those education and training in the remaining portion of their life in the society. This research work aims at focusing on the necessity and implication of education and training in the life of the prisoners of Bangladesh. In addition, this study finds out the facade of the real conditions of the prisoners through a number of case studies.

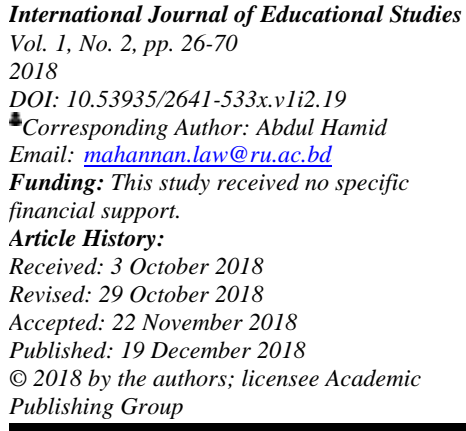




\section{Introduction to Rights of the Prisoners}

\subsection{Introduction}

No human being is born as criminal. There are some particular circumstances which often compel a human being to commit crimes. There are socio-economic, socio-geographical and geo-political reasons behind committing crimes by human beings. However, the law to which a person is a national says that he/she must be brought before law and if he/she commits a crime, has to undergo punishment specified by penal laws. He or she can not make an excuse that the crime was done unwillingly rather elements have compelled him or her to commit the crime. Sometimes, it is seen that there are so many circumstances when an accused remains in the police custody for years and finally after a considerable period of time the court declares the accused innocent. This considerable period of time that he/she passes in the prison cell in vain. This period of time is lost from his/her life for good.

Every human being is entitled to inherent rights of nature. They are entitled to possess these rights subject to the provisions of the law applied to the land. The concept of society is meaningless without the presence of these inherent rights of a human being. ${ }^{1}$ The words human and rights are being collectively used to mean those legal claims which are related to mankind. And such type of universal rights of human beings grew in mankind from the very ancient time. ${ }^{2}$ These rights are so inherent that without these a man cannot think of living with due dignity. The absence of human rights in any society is basically a denial of human dignity. ${ }^{3}$ However, the protection and promotion of human rights among many others depend on an effective criminal justice system. Criminal justice means different stages of court proceedings functions of police and prosecutions such as filing of a case, investigation thereof, framing of charge, trial, justifying the evidences etc.

Human rights therefore represent minimal moral standards for human society. ${ }^{4}$ Every country has its own criminal law system under which certain acts or omission is regarded as crime and sufficient sanctioning measures are there. An individual who is charged with the commission of a crime is regarded as an accused. Accused who is arrested and forwarded for criminal trial is called a prisoner. A prisoner has the right to defend himself against the charges brought against him/her by every facility ensured by the law. ${ }^{5}$

Many efforts in international and in municipal arena are found as well for the promotion and protection of the rights of public in general and of the prisoners in particular. For this purpose some important and remarkable human rights instruments are discussed in this work. Like the Universal Declaration of Human Rights, 1948, ${ }^{6}$ the International Covenant on Civil and Political Rights, $1966,{ }^{7}$ the United Nations Standard Minimum Rules for the Treatment of Prisoners, 1957, the United Nations Draft Body of Principles for the Protection of All Persons under any form of Detention or Imprisonment, 1988 and in various domestic legislations.

Our present judicial system is surrounded by thousands of problems. Throughout the whole country paucity of courts or judges are common feature of our judicial system. Moreover, the unhygienic environment in the prisons caused by the overcrowding of prisoners need to be examined for the protection of the rights of the prisoners. Protection of the rights and interests of the prisoners as well as there psychological and economic assistance is vitally important for fair implementation of criminal laws and also for gaining public confidence in criminal justice system. Therefore, this study seeks to explore those particular factors that impair the criminal justice system, which is essentially important for protection of the rights of prisoners.

This study also seeks to correlate international and national protection of human rights which are applicable to prisoners' in particular criminal proceedings. The condition of prisoners in the jail custody of

${ }^{1}$ ME Bari, 'The Universal Declaration of Human Rights-The Magna Carta of Mankinds', in Human Rights in Contemporary International Law, (Dhaka, 1997), 27

2 Justice Mozammel Haque, 'Human Rights and Rights to liberty: Before and Now', in Human Rights Law, (Dhaka, 1997), 267

${ }^{3}$ Human Rights Today-UN Briefing Papers, (UN Publications: October, 1998), 6

${ }^{4}$ Morris B Abram, 'Freedom of Thought Conscience and Religion', in Journal of the International Commission of Jurists, (1997), 40

${ }^{5}$ Manjula Batra, Protection of Human Rights in Criminal Justice Administration, (Deep \& Deep Publications, New Delhi: 1989), 7

${ }^{6}$ Hereinafter referred to as the UDHR

${ }^{7}$ Hereinafter referred to as the ICCPR 
Bangladesh has been set forth in detail and a comparison with different international and domestic instruments has been dealt in this study.

The purpose of this study is to show and examine the legal position of prisoners and recognition of their rights including education and training of prisoners within the purview of international as well as municipal law of Bangladesh. This study also reflects on human rights situation with regard to the prisoners in Bangladesh.

Another issue has been taken into consideration that, a human being of any age may commit crime. During the period an accused or a convict remains within the walls of the prison cells he/she cannot usually take formal education of the land and there is a high apprehension that after his or her release he/she may be involved again in crime. Therefore, if these persons can achieve necessary education and training during their stay in prison they can lead a better life after being released from jail custody by utilizing those education and training in the remaining portion of their lives in the mainstream society. This research work aims at focusing on the necessity and implication of education and training in the life of prisoners of Bangladesh.

\subsection{Objectives of the Study}

This study is an attempt to make an evaluation of the procedural guarantees as accorded to the accused under international law and laws of Bangladesh. Considering the vastness of the area of criminal justice this study has been focused on the condition and training of prisoners. In view of the studies the goal is formulated in some specific objectives as follows:

(i) To identify the grounds of violation of the rights of prisoners;

(ii) To focus on the ways of making the current laws effective for reformation of prisoners by mentioning their success and failure;

(iii) To develop social awareness about the rights of prisoners;

(iv) To promote effectiveness of the authority for establishing human rights and to accelerate dynamism in playing effective role of the authority by portraying abuse of laws; and

(v) To find out ways and means of taking effective measures for establishing the rights of prisoners regarding education and training.

In order to procure these objectives some standards are necessary to evaluate the jail situation in Bangladesh. With this end in view, the study aims to scrutinise policies, general principles of law, norms, customs, mechanisms and practices concerning prisoners. In this regard, the study has reviewed and analysed the secondary literature, law and practices of Bangladesh in accordance with the methodology of the study and the relevant data.

\subsection{Methodology of the Study}

This study has examined the law and practice relating to the rights of the prisoners in Bangladesh. It has evaluated the present conditions of laws and practices in this respect. In order to give complete shape to the study, a range of research methods has been used:

(i) review of secondary literature and instruments on prisoners rights;

(ii) examination of the constitutional guarantees regarding probation and parole in Bangladesh;

(iii) analysis of statutory law and case law relating to prisoners in Bangladesh;

(iv) review of relevant public records, available statistical data and annual reports of various NGOs;

(v) case studies of specific incidents relating to the rights of prisoners; and

(vi) collection and analysis of relevant data.

Discussion on the conceptual issues based on the secondary literature including books, journals, electronic materials, constitutional law, statutory laws and case laws.

a. Study Design: The study is empirical and at the same time it is focused on previous records and future possibilities.

b. Period of Study: The study has covered a period of 10 (ten) years from 1996 to 2006 . This study concentrates on the above-mentioned period to highlight actual position of the prisoners under its prevailing Constitution, laws and practices thereof during two regimes namely, Shiekh Hasina (19962001) and Khaleda Zia (2001-2006). 


\subsection{Sources and Modes of Data Collection}

The study is based on both primary and secondary data. The primary data has been collected from field survey. An interview schedule has been used as a technique of primary data collection. The researcher has visited the prison and police administration within greater Rajshahi for collecting information through formal personal interview with the persons concerned. The secondary data has been collected from the literature on the topic, Annual Reports of major non-governmental organizations i.e., "Bangladesh Manobadhikar Shamannoy Parishad (BMSP)", Bangladesh Rehabilitation Centre for Trauma Victims (BRCT), Bangladesh Legal Aid and Services Trust (BLAST), Ain O' Shalish Kendra (ASK), Odhikar etc. and documents on human rights i.e., Amnesty International, Human Rights Watch, UDHR, ICCPR etc. Moreover, information has been collected from the website of various national and international organizations. The collected data has been classified, analysed and tabulated according to the different objectives and variables of the study.

On the basis of evaluation some proposals by way of recommendations has been made in the conclusion of each chapter to improve the prison condition in terms of education and training in Bangladesh. An overall conclusion has been drawn in the last chapter of the study.

\subsection{Scopes and Limitation of the Study}

The scope of the study relates to the jail administration in Bangladesh and ranges for a period of ten years i.e., from 1996 to 2006. This study does not go beyond the said period but it may discuss an issue beyond this period if it seems to be very important or notorious. The study area is within greater Rajshahi as because Rajshahi will be convenient for the researcher in collecting information and data, as it is the workplace of the researcher. Since the prison conditions of different parts of Bangladesh are almost same, it is presumed that Rajshahi will reflect the whole scenario of prisoners. It may be noted that this study has not specifically focused on women prisoners or juvenile offenders but if there is any prominent or important case this study may discuss that issue. The study has been continued for a period of one year. Due to constraint of time and financial support the study is limited in respect of time and place as mentioned above.

\subsection{Rationales and Justification of the Study}

It is hoped that this study makes a significant contribution to the concepts of the rights of prisoners. It will help the policy makers, legislators and researchers to know about the problems and prospects of the rights of the prisoners. The findings of this study are intended to help the government to improve the existing laws relating to the jail situation in Bangladesh.

As the study is concerned with the violation of laws relating to education and training of prisoners and protections thereof, as well as effectiveness of laws, steps of Government, awareness of people and respect to laws, which are the glaring issues of day, it deserves some inordinate significance. It will be a new combination for the researcher, because as far as known, there has been no research work done as yet on this issue in Bangladesh. It is expected that this recent issue can be treated as an important and valuable source for the workers on this subject. The findings of the research will be helpful for the people, especially the prisoners who may be inflicted in a case or detained in custody; further prisoners will be encouraged to find ways for establishing their rights.

Moreover, it will open wide opportunities for other researchers concerned with this arena. This research work may be helpful for the students of law to enrich their knowledge. Besides, many institutions, agencies and organizations will benefit from this type of new research work.

\subsection{Review of Literature}

Criminal justice administration is a fast growing subject and interaction of the three Government organs i.e., executive, legislature and judiciary in a democratic state has become a subject of discussion and research from the days of the formation of the democratic government in society, innumerable books and articles are written on this topic. Many books regarding criminal justice administration are found in different libraries; and mostly some aspects of the activities of the Law Enforcing Agencies (LEA) are found in Police Regulations of Bengal, Criminal Justice System Administration and Police Administration in Bangladesh. Because of the changing patterns of the society and human behaviour with the development of science and technology earlier literature on this topic is becoming insufficient to give exact information and protection.

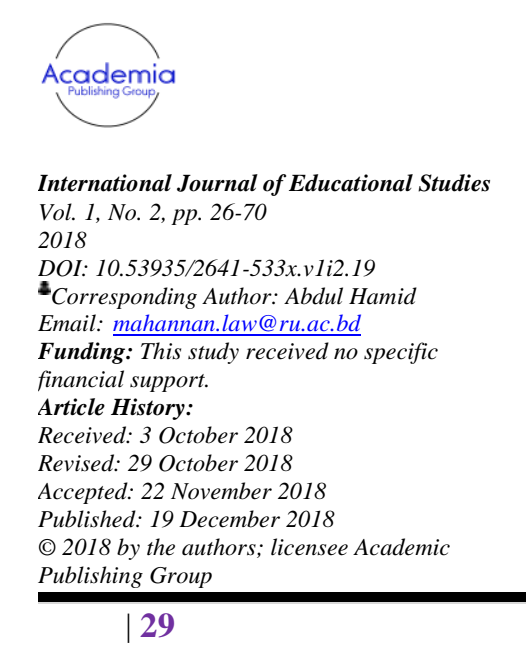


And none of them contains any adequate information about what Bangladeshis need to know on the rights of the prisoners.

On the legal relationship some other books, which bear much significance are; Protection of Human Rights in Criminal Justice Administration by Manjula Batra, Criminal Justice System Administration by M. Enamul Huq, Police Administration in Bangladesh by ABMG Kibria, Criminal Investigation by John Adam and John Collyer Adam and Constitutional Law of Bangladesh by Mahmudul Islam.

Apart from these works, a list of other books, articles, documents, statutes, and journals on different aspects of the rights of the prisoners may be found but none of them has dealt with this research topic in the light and details as it has been intended to be done in this work. In none of them could be found an unbiased and in-depth treatment of this burning research area. Attempts have been made in this work to suggest reform where necessary and update the existing laws so that an effective and efficient prison system is ensured in a fruitful way.

The purpose of this study is to show and examine the legal position of prisoners and recognition of their rights within the purview of international law as well as municipal law of Bangladesh. The study has also reflected human rights situation with regard to the prisoners in Bangladesh.

\subsection{Organisation of the Study}

The study has devoted mainly towards assessing the implementation of national and international instruments regarding rights of the prisoners in Bangladesh. To highlight the issues the whole research work has been divided into NINE chapters and each of the chapters contains the details of the subject discussed below.

The first chapter is introductory with description of the rights of the prisoners and the jail situation in Bangladesh. This chapter outlines the aims and methods of the study. It discusses the scope and limitation of the study, the objectives of the study, the research methodology and the review of literature.

The second chapter provides with the conceptual issues relating to rights of the prisoners. This chapter explains the terminologies which are used in this study.

The third chapter focuses on the right of prisoners in the international instruments.

The fourth chapter deals with the right of prisoners in the domestic instruments. In this chapter a discussion has been made on the prison system and laws are prevailed in Bangladesh.

The fifth chapter deals with the impact of human rights provisions in the life of prisoners, right to a fair trial and rights of prisoners in Bangladesh. This chapter highlights the rights available to the accused at the undertrial stage and also discusses the prisoners' rights including the jail situation in Bangladesh.

The sixth chapter attempts to elucidate the initiatives taken by the government regarding prisoners.

The seventh chapter deals with constraints and limitations of the enactment for the treatment of the prisoners in Bangladesh.

The eighth chapter shows the state of human rights of prisoners in Bangladesh. This chapter is based on interviews with lawyers, judicial officers, police officers, jail officers and with prisoners.

The ninth and last chapter presents a general conclusion including the findings and recommendations in the light of findings. The recommendations are made to update the existing laws to provide due and just relief to the prisoners in respect of education and training. 
Every chapter specially deals with issues relating to the rights of the women accused. It clarifies what types of rights the women accused are entitled to. The objective of this section is to ponder over those rights guaranteed to a woman accused in criminal justice.

\subsection{Conclusion}

This study presents an evaluation of the existing conditions of the prison system in Bangladesh. The final chapter summarises the major findings of the study and outlines the possible recommendations to strengthen the prison system in order to establish human rights of the prisoners.

Albeit Bangladesh has a good criminal justice system and design; where the lacking is in the coordination of the three principal agencies that is court, prisons and police. However, expediting and smoothing the trial process alone cannot solve the overall overcrowding situation and ensure human rights in prisons. Much more needs to be done to slow down the inflow of prisoners to the prisons as well as ensuring their proper reintegration to the society. The Bangladesh government has however shown the responsibility to understand the problem and is the only developing nations that has stepped forward forming partnership with development organisations and non-government agencies to solve the crisis.

\section{Conceptual Issues Relating To Rights of the Prisoners}

\subsection{Introduction}

Confinement in prison symbolizes a system of punishment and also a sort of institutional placement of under-trials and suspects during the period of trial. ${ }^{8}$ Since there cannot be a society without crime and criminals the institution of prison is indispensable for every country. For better understanding this chapter discusses some fundamental issues relating to the rights of the prisoners.

\subsection{Prison System}

A prison penitentiary or correctional facility is a place in which individuals are physically confined or interned and usually deprived of a range of personal freedoms. Prisons are conventionally institutions and it is a very important part of the criminal justice system of a country.

In many countries the term jail is more popular that is a synonym of prison. Prisons may also be used as a tool of political repression to detain political prisoners, prisoners of conscience and enemies of state. In time of war or confide the defeated side are considered as war prisoners and they are also detained in prisons. In criminal cases, a criminal defendant may also be held in prison while awaiting trial or a trial verdict. If he is founded guilty, the defendant will be convicted and may receive a custodial sentence requiring imprisonment.

\subsection{Types of Prisons}

In Bangladesh, there are four types of jail or prisons namely-

i. Central jail

ii. District jail

iii. Subsidiary jail and

iv. Thana jail

These classifications are made as per Section 60(a) of the Prisons Act 1894. There are 80 jails in total in Bangladesh. ${ }^{9}$ The number of the central jails in Bangladesh is nine located at Dhaka, Rajshahi, Jessore, Comilla, Chittagong, Sylhet, Rangpur, Barisal and Mymensingh.

\section{District Jails}

International Journal of Educational Studies Vol. 1, No. 2, pp. 26-70

2018

DOI: 10.53935/2641-533x.v1i2.19

Corresponding Author: Abdul Hamid

Email: mahannanlaw@ru.ac.bd

Funding: This study received no specific

Funding: This study
financial support.

Article History:
Received: 3 October 2018

Revised: 29 October 2018

Accepted: 22 November 2018

Published: 19 December 2018

(C) 2018 by the authors; licensee Academic

Publishing Group

| 31
There are 56 district jails which are located at the District Head Quarters. In these jails all types of prisoners are confined except prisoners of over 5 years imprisonment.

\section{Subsidiary jails}

All the subsidiary jails have been converted into district jails.

\footnotetext{
${ }^{8}$ Sharma PD, Police and Criminal Justice Administration in India, (1985), 145

${ }^{9}$ Sarkar AH, Criminology: Theory and Analysis, Kollol Prokashony, Dhaka: 2005, 229.
} 


\section{Thana jail}

There are 16 police station jails located at thana head quarters, which is called thana jail.

The total registered capacity of these jails is $28394 .{ }^{10}$ According to one report in 1997 the number of prisoners was $44285 .{ }^{11}$ Another report says that the actual number is three or four times of the actual capacity. According to Manobadhikar in 1997 the total number was $93000 .{ }^{12}$ All jails are over crowded and completely unsuitable to live. Prisoners are often deprived of the rights provided in the Jail Code.

The capacity of prisons and the number of prisoners throughout the prisons in Bangladesh can be measured from the following table: ${ }^{13}$

\begin{tabular}{lll}
\hline Year & Capacity & Actual number of Prisoners \\
\hline $\mathbf{1 9 9 6}$ & 21620 & $\mathbf{4 4 7 2 0}$ \\
$\mathbf{1 9 9 7}$ & 21620 & $\mathbf{4 5 1 7 4}$ \\
$\mathbf{1 9 9 8}$ & 22439 & $\mathbf{4 7 7 6 4}$ \\
$\mathbf{1 9 9 9}$ & 23942 & $\mathbf{5 2 3 7 0}$ \\
$\mathbf{2 0 0 0}$ & 23942 & $\mathbf{5 9 8 8 5}$ \\
\hline $\mathbf{2 0 0 1}$ & $\mathbf{2 4 9 9 7}$ & $\mathbf{6 6 6 2 5}$ \\
\hline
\end{tabular}

\subsection{Prisoners}

Confinement in prison symbolizes a system of punishment and also it indicates one kind of institutional placement of under-trials and suspects during the period of trial. ${ }^{14}$ Normally the ultimate object of imprisonment system is to confine the offender from committing offences and also to bring about a reformatory change in his/her mind. The isolated life in the prison and incapacity of inmates to move freely make a person think that brings a correctional change in his/her mind. If the offender is kept in the prison cells, the committing of crimes by that offender can be under control by eliminating those criminals from the society. In another sense, it can be said that prisons also serve as institution for the reformation and rehabilitation of the offenders. But for the main purpose of the punishment, prison serves to keep the wrongdoer under custody and jail. ${ }^{15}$ Generally, prisoners mean those persons who are kept in the prison cells for being accused or convicted or detained under the laws of the land.

There is no age limit of a prisoner. Any person of any age can be a prisoner. Even if any party to a war is defeated by the other, in that case they are designated as war prisoners. They are to be treated under the provisions of the Geneva Conventions, 1949, international customary laws and usages and under the agreement if there exists among those parties. In exceptional cases, some persons are also kept under police custody or custody under the court for a certain period and after the expiration of which by fulfilling some conditions they are released. These individuals do not come within the category of prisoners.

\subsection{Types of Prisoners}

Prisoners are of two types-

i. Criminal Prisoners

ii. Convicted Prisoners.

Criminal prisoners are those prisoners who are convicted to jail either under writ or warrant or order of any court or authority exercising criminal jurisdiction or by an order given by a court martial, they can be termed as accused or under trial prisoners.

${ }^{10}$ The Daily Star, Dhaka, 13 June 2004

${ }^{11}$ Annual Report of BRCT, 1997, State of Human Rights, (Published in 1997; Dhaka), 52

${ }^{12}$ Manobadhikar, 31 August 1999

${ }^{13}$ Bangladesh Kishore Aparadher Bichar Babostha O' Shishuder Birudhe Sohingsota Songkranto Borshopunji (The Judicial System of Juvenile Offences and Annual Report regarding Violence against Children in Bangladesh) Save the Children, UK and Odhikar, 2001), 30

${ }^{14}$ PD Sharma, Police and Criminal Justice Administration in India, (1985), 145

${ }^{15}$ NV Paranjape, Criminology and Penology, (Ninth edition, 1966: Central Law Publication, Allahabad, India), 244 
Convicted prisoners are those prisoners who are committed to jail under sentences given by a court or court martial. Such types of prisoners also include a prisoner who is detained under the Code of Criminal Procedure, 1898 or under the Prisons Act, 1894.

In Chapter XV of the Jail Code of Bangladesh certain classes of prisoners are dimensional which shall be kept entirely separate from the others. ${ }^{16}$ Those classes are:
1. Civil Prisoners
2. Under trial prisoners
3. Male Prisoners
4. Female Prisoners
5. Male prisoners under twenty one years of age
6. Male prisoners who have not arrived at the age of puberty
7. Other male prisoners who are convicted.

Besides the above mentioned prisoners, there is another kind of prisoners who are called as the juvenile prisoners.

Civil prisoners are those prisoners who are convicted in civil cases. In this cases, if the court is satisfied that the person against whom the civil proceedings has been taken and that person causes a great damage to the reputation and property of the petitioner then the order of compensation and also the order of civil jail be posed. In this matter the cost of such civil jail should be borne by the petitioner.

Under-trial prisoners are those prisoners who are brought under the court proceedings. But the final decision of the court is yet to come. This type of prisoners may be convicted or be released upon the judgment of the court.

\section{Male Prisoners}

In our country most of the prisoners in prison cells are male prisoners. They are of different ages, i.e. male prisoners who are under the age of twenty one years, male prisoners who have not arrived at the age of puberty etc. Most of the jails in Bangladesh are mainly overcrowded by male prisoners. About eighty or more percents of the prisoners are male. The life of these male prisoners in Bangladesh is regulated by the provisions set out in the Jail Code of Bangladesh. The Jail Code provides specific provisions regarding treatments of these prisoners.

\section{Female Prisoners}

Beside male prisoners, there are a number of female prisoners in the prisons of Bangladesh. The life of the prisoners both male and female in Bangladesh is regulated by the specific provisions of the Prisons Act, 1894 which is commonly known as the Bengal Jail Code. The Code provides for female prisoners specific provisions for there better condition in the prison cells.

\subsection{Education for the Prisoners}

For the harmonious and constructive development of human mind education is a must. It has a very large scale effect on the formation of human mind. The general concept regarding education is, it is an act or experience which has a formative effect on the mind, character, or physical ability of an individual. In technical sense, education can be compared with a process by which society deliberately transmits its accumulated knowledge, values and skills from generation to generation through institutions. ${ }^{17}$ In the Constitution of Bangladesh education has assumed the most important shape of fundamental human rights. It is a right that every human being is entitled to enjoy not because of the guarantee of any state organ but because he or she is a member of the entire human community.

A prisoner has the right to get the delighting touch of education. He may be accused or be convicted, but he/she has the right to be enlightened with the light of education. Prison education has to be similar with the formal education system, but it is not mandatory. It may be in the form of vocational training or may be in institutional form. The prison authority may play the key role in this regard. And also, in association with the

\footnotetext{
${ }^{16}$ The Bengal Jail Code, 1894, Chapter XV, Rule 616

${ }^{17}$ George F. Kneller, Introduction to the Philosophy of Education, (New York: John Wiley and Soni, 1971), 20-21
}

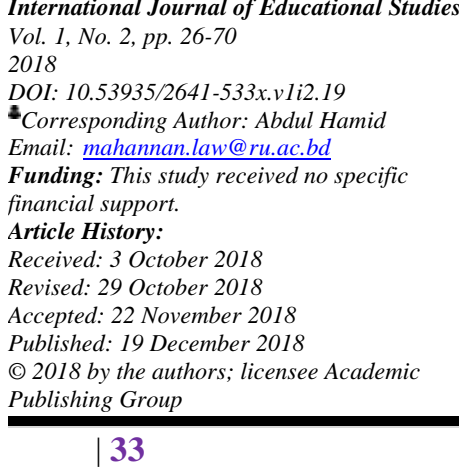


prison authority, any other private institutions may provide the facility to the prisoners as a part of their rehabilitation, reintegration and preparation of their free life in future.

\subsection{Training for the Prisoners}

Training includes the act or process of teaching or learning a skill discipline etc. ${ }^{18}$ The word training is meant generally, the technical education which develops the expertise in a particular group of techniques or technology. However, training may cover the education that is vocational in nature and also training for the purpose of enabling the learners for their professions that mainly depend on practical or manual activities and it is traditionally non-academic and related to a specific trade, occupation or vocation.

Training for the prisoners is a very rational right of the prisoners. This training indicates that prisoners in the prison cell should get training either in the vocational or technical side. This is so done to help them in future professions, life outside the prison to earn livelihood in a legitimate way. This training may include computer learning. In the modern age, the person who has the efficiency in computer knowledge has a greater demand than any other skill. So, if the prisoners can be well skilled in computer education in the prison cell, they can be turned into our assets instead of being our burden. The female prisoners could get training on computing, sewing, knitting and other relevant works. We all know that garments sector is now considered as the thrust sector of Bangladesh. And if the women staying in the prisons are well trained in above mentioned activities they can easily be employed in our vast developing garments industries after they get release from the prison cell and it will help them to lead a respectable life in the society and also help them to stand on their foot.

\subsection{Human Resources Development}

Human Resources denote an increasingly broadening term that refers to managing human capital, the people of an organization. The field has moved from a traditionally administrative function to strategic one that recognizes the link between talented and engaged people and organizational success. The field draws upon concept developed in Industrial or organizational psychology and system theory. Human Resources have at least two related interpretations depending on contest. The original usage derives from political economy and economics, where it was traditionally called labour, one of four factors of production although this perspective is changing as a function of new and ongoing research in to more strategic approaches at national levels. In industrial sector the usage is used in terms of human resources development and can go beyond just organizations to the level of nations. The more traditional usage within corporations and business refers to the individuals within the portion of the organization that deals with hiring, firing, training, and other personal issues typically referred to as human resources management.

At the organizational level a successful Human Resources Development programme will prepare an individual to undertake a higher level of work, organized learning over a given period of time, to provide the possibility of performance change. ${ }^{19}$ In these settings, Human Resources Development is the framework that focuses on the organizations competencies at the first stage, training and then developing the employee, through education to satisfy the long term need. The broader concept of national and more strategic attention to the development of human resources is beginning to emerge as newly independent countries face strong competition for their skilled professional and the accompanying brain drain they experience.

Through the Human Resources Development instrument, the prisoners of our different jails may be turned into our manpower in the long run. And through these instruments a revolutionary change can be brought into our society. This is because that the prisoners will be well trained and educated and if a higher optimism scatters among themselves there will remain a less possibility of them to turn back to their past life and it will be very much helpful for their rehabilitation. Human Resource Development would gain a permanent role within the jail territory increasingly as not only on academic discipline but as a central theme in development policy.

We expect released prisoners not to repeat crimes in fear of going back to the hell called prison. Bangladeshi prisons no doubt are mini hells where on average, 200 inmates are crammed into a 40 square metre space and in many cells people have to wait for their turn to sleep. Over the years, overcrowding has

\footnotetext{
${ }^{18}$ Illustrated Oxford Dictionary, (Oxford University Press: Dorling Kindersley Limited, 2008), 882

${ }^{19}$ Nadler, 1984
} 
become so worse that the Prison Directorate openly admits that they are failing to meet the United Nations (UN) defined minimum standards of adequate light, air, decency and privacy in prison.

So why should we be concerned of the ghastly situation inside the four walls of the prison? Even if we do not take human rights into consideration, we need to address the threat that the overcrowding conditions of the prisons of Bangladesh pose to this part of the wall. The prisons are breeding grounds of contagious diseases like pulmonary tuberculosis, HIV/ AIDS, and affected prisoners are likely to bring back their prison legacy into the society, when released. Moreover, the prisons are generating more crimes than repentance, as inmates of all age and classification whether children, mentally ill, addicts or murderers share the same space. 72 percent of inmates of Bangladesh are untried and therefore legally innocent. ${ }^{20}$ In most cases, these are poor people with no lawyers to defend them and with no idea about their legal rights. Even the Legal Aid Act, 2000 enacted to help the poor and the vulnerable failed to reach the targeted people because of the flaws of the process and the ironically 75 percent of fund allocated annually for the purpose remains unutilised.

The chart below shows the inhumane conditions of the prisoners in randomly selected district jails in Bangladesh, as on 22 September 2010:

\begin{tabular}{lll}
\hline Central or District Jail & Capacity of Prisoners & Actual Prisoners \\
\hline Sylhet & 1210 & $\mathbf{2 8 7 5}$ \\
Dhaka & 2682 & $\mathbf{8 1 7 3}$ \\
Mymensingh & 1200 & $\mathbf{2 0 1 4}$ \\
Manikganj & 100 & $\mathbf{5 7 0}$ \\
Tangail & 875 & $\mathbf{1 7 4 6}$ \\
\hline Netrakona & $\mathbf{2 5 0}$ & $\mathbf{7 2 3}$ \\
\hline
\end{tabular}

Source: Report regarding the Statistics of prisoners in different jails of Bangladesh 2010, Jail Authority, Dhaka (Copy on file with author)

The lack of rehabilitation and training programmes for prisoners also makes it difficult to reintegrate them into the society. Resources available are all used up to ensure food and security in the overcrowded prisons and thus proper reformatory steps remains a far-fetched dream.

\subsection{Conclusion}

The reintegration process of the prisoners into the mainstream society is not a one day task. It takes time and patience. Sufficient education, proper training and developing their skills in different field may reintegrate them. There should be a harmonious relationship in understanding of duties among the role players who are concerned in this task. Government should come forward with special care in this arena. It needs sufficient funds and support to implement all the jobs.

\section{Right of Prisoners in the International Instruments}

\subsection{Introduction}

The concept of human rights and its violation is as old as the creation of human beings. Man lives in this world for a specific period of time. In this short life he or she needs the protection of these rights. Though human rights are inseparable, these are violated by human beings themselves.

In order to stop violation of human rights, many International instruments have been enacted and created. The United Nations (UN) was established for the very purpose of protection and promotion of human rights since its inception. Efforts have been made to find out the causes of violation of human rights and remedies thereof.

Before the birth of UN there was no international provision regarding protection of human rights though there were national or regional instruments for it. These instruments had no world-wide application.

Human rights received global recognition only after the establishment of the UN on 24 October 1945. The

International Journal of Educational Studies Vol. 1, No. 2, pp. 26-70

2018

DOI: $10.53935 / 2641-533 x . v 1 i 2.19$

Corresponding Author: Abdul Hamid

Email: mahannan.law@ru.ac.bd Funding: This study received no specific

Funding: This study
financial support.
Article History:

Article History:

Revised: 29 October 2018

Accepted: 22 November 2018

Published: 19 December 2018

(c) 2018 by the authors; licensee Academic

Publishing Group

$\mid 35$
$\mathrm{UN}$ recognizes human rights and fundamental freedoms which are the cornerstones for future maintenance of peace and international security.

After the establishment of the UN, throughout the twentieth century a number of international instruments regarding protection and promotion of human rights have been created.

\footnotetext{
${ }^{20} \mathrm{http}: / /$ www.thedailystar.net/magazine/2010/10/03/s_feature.htm
} 


\subsection{Human Rights Provisions for the Prisoners}

In modern civilization, every country is under an obligation to keep peace and security in the world by providing criminal justice system. In every criminal justice system the prisoners are an important part thereof. This study seeks to show the provisions of different international instrument regarding prisoners i.e., treatment with prisoners, their rights, facilities, trial proceedings, etc.

After the establishment of UN, the UDHR was the first international instrument which steps forward to protect the rights of the prisoners. The UDHR declares that all are equal before law and are entitled to equal protection of law. All are entitled to equal protection against any discrimination. This is discussed in Article 7 of the UDHR. The UDHR included provisions regarding the privacy of every person. Freedom from arbitrary interference with privacy, family, home and correspondence are ensured by this declaration. ${ }^{21}$

The same is discussed in Article 14(1) of the ICCPR. This Article states, "All persons shall be equal before the courts and tribunals". In the determination of any criminal charge against him, or of his rights and obligations in a suit of law, every one shall be entitled to a fair and public hearing by a competent, independent and impartial hearing".

Article 8 of the UDHR declares that every one has the right to an effective remedy by the competent national tribunals for acts violating fundamental rights granted him by the constitution or by law. The same view is expressed in Article 14(1) of the ICCPR. So, if any person is accused of committing of any crime and imprisoned, he/she has the right to a fair trial by the competent courts or tribunals. Arbitrary arrest, detention or imprisonment is prohibited by different international instrument.

Article 1 of the UDHR states that, "No one shall be subjected to arbitrary arrest, detention or exile". The same matter is discussed in Article 9(1) of the ICCPR. In Article 9(1) of the ICCPR it is clearly stated that, "every one has the right to liberty and security of person". No one shall be subjected to arbitrary arrest or detention. No one shall be deprived of his liberty except on such grounds and in accordance with such procedure as are established by law.

It is clear that the UDHR along with the ICCPR set a bar against the arbitrary arrest or detention. The presumption of innocence has been cited in the provision of UDHR. Article 11 of UDHR clearly states that-

i. Every one charged with a penal offence has the right to be presumed innocent until proved guilty according to law in a public trial at which he has had all the guarantees necessary for his defence.

ii. No one shall be held guilty of any penal offence on account of any act or omission which did not constitute a penal offence under national or international law, at the time when it was committed, nor shall a heavier penalty be imposed than the one that was applicable at the time the penal offence was committed.

In the ICCPR the view of presuming innocence has also been found. Article 14(2) of ICCPR provides that, "Every one charged with a criminal offence shall have the right to be presumed innocent until proved guilty according law". So, before the final decision of the court all the prisoners should be presumed innocent and be treated with respect and full dignity.

In the determination of any criminal charge against a person, he/she shall be entitled to the minimum guarantees of being informed promptly and in detail in a language which he understands of the nature and cause of the charge against him and he or she shall have adequate time and facilities for the preparation of self defence. ${ }^{22}$

In most cases prisoners remaining inside prison cells face inhuman or degrading treatment or punishment. There are specific provisions in this regard in different international instruments. Regarding this matter the UDHR in Article 5 says, "No one shall be subject to torture or to cruel, inhuman or degrading treatment or punishment". ${ }^{23}$ This indicates that in the jail custody the prisoners not to be treated inhumanly subjected to any cruelty or degrading punishment inflicting upon him/her.

The same view is expressed in the provisions of the ICCPR. Article 7 of the ICCPR says that, "No one

International Journal of Educational Studies Vol. 1, No. 2, pp. 26-70 2018

DOI: 10.53935/2641-533x.v1i2.19

Corresponding Author: Abdul Hamid Email: mahannan.law@ru.ac.bd Funding: This study received no specific Funancial support.

Article History:

Received: 3 October 2018

Revised: 29 October 2018

Accepted: 22 November 2018

Published: 19 December 2018

(C) 2018 by the authors; licensee Academic

Publishing Group

| 36 shall be subjected to torture or to cruel inhuman or degrading treatment of punishment. In particular, no one shall be subjected without his free consent for medical or scientific experimentation".

\footnotetext{
${ }^{21}$ The Universal Declaration of Human Rights, Article 12

${ }^{22}$ ICCPR, Article 14(3)

${ }^{23}$ UDHR, Article 5
} 
In Article 10(1) of the ICCPR, it is clearly mentioned that all persons deprived of their liberty shall be treated with humanity and with respect for the inherent dignity of the human person. This Article clears that a person under his/her imprisonment shall have the right to be treated with humanity and with full dignity of human person. He or she should not be subjected to degrading treatment only because that he or she is a prisoner rather he/she should be treated as a human being of the society.

Having regard to Article 5 of the UDHR and Article 7 of the ICCPR, both of which provide that no one shall be subjected to torture or to cruel inhuman or degrading treatment or punishment and also having regard to the "Declaration on the Protection of all persons from being subjected to Torture and other cruel, Inhuman or degrading Treatment or Punishment" adopted by the General Assembly on 1 December 1975 desiring to make more effective struggle against torture and other cruel, inhuman or degrading treatment or punishment throughout the world, a specific convention was adopted and opened for signature, ratification and access by General Assembly resolution 39/46 of 10 December, which entered into force on 26 June 1987.

In Article 4 of the UN Torture Convention all acts of torture are considered to be offences under criminal laws of its member states. Also, in Article 7(3) of this Convention it is said that, "Any person regarding whom proceedings are brought in commotion with any of the offences referred to in Article 4 shall be guaranteed fair treatment at all stages of the proceedings".

Again, the matter of privacy is mentioned in different international instruments. In prison cells, the women prisoners shall have the right of privacy. The female prisoners are to be kept in a separate enclosure and their privacy should be strictly ensured that no male officer has an entrance into that enclosure unless he has a duty intended therein.

Article 12 of the UDHR clearly mentions that, "No one shall be subjected to arbitrary interference with his privacy, home or correspondence, not to attacks upon his honour and reputation. Every one has the right to the protection of law against such interference or attacks". Yet the privacy of prisoners is not the same as compared to persons outside prison.

Again, the ICCPR in Article 17 emphasizes upon this matter saying that no one shall be subjected to arbitrary or unlawful interference with his privacy, family, home or correspondence or to unlawful attacks on his honour and reputation. But the privacy of an ordinary person and a prisoner is not same. The privacy of the prisoners is restricted by law. In spite of this restriction imposed by law, no prisoner should be compelled to testify against him or herself or to confess guilt.

This matter is clearly mentioned in Article $14(3)(\mathrm{g})$ that, "every on shall be entitled to the minimum guarantee of not to be compelled to testify against himself or to confess guilt".

A number of international instruments have provided for standards for treatment of prisoners. Among these the most important is the Standard Minimum Rules for the Treatment of Prisoners. This Standard Minimum Rules was adopted by the First United Nations Congress on the Prevention of Crime and the Treatment of Offenders held at Geneva. ${ }^{24}$

This Standard Minimum Rules enjoins the authority of every prison to keep a bound Register where the detail particulars of the prisoners will be recorded. It imposes an obligation to keep different types of prisoners in different parts of the prison taking account of their sex, age and criminal record. It requires the prison authority to keep untried prisoners separately from convicted prisoners, women from men, and young prisoners from adults. All sleeping accommodation, as per the provision of the Standard Minimum Rules, shall meet all the requirements of health, due regard being paid to climatic conditions and particularly to cubic content of air, minimum floor space, lighting, heating, and ventilation. The windows shall be large enough to enable the prisoners to read or work by natural light. The sanitary installations shall be adequate to enable every prisoner to comply with the needs of nature when necessary and in a clean and decent manner. Prisoners shall be provided with water and with such toilet articles as are necessary for health and cleanliness. Every prisoner shall be provided with an outfit of clothing suitable for the climate and adequate to keep him/her in good health, and shall be provided with a separate bed. Every prisoner shall be provided at the usual hours with food of nutritional value adequate for health and strength, of wholesome quality and well prepared and served. ${ }^{25}$

\footnotetext{
${ }^{24}$ It was approved by the Economic and Social Council by its Resolutions 663 C (XXIV) of 31 July 1957 and 2076 (LXII) of 13 May 1977

${ }^{25}$ The Standard Minimum Rules, Sections 37, 40 and 41
} 
Standard minimum rules further provide that prisoners shall be allowed under necessary supervision to communicate with their family and reputable friends at regular intervals, both by correspondence and by receiving visits. The Rules enjoins the prison authority to establish a library for the use of all categories of prisoners and ensure arrangements so that the prisoners can perform their religious prayers.

It is estimated globally there are more than 9 million people in prison, either as pre-trial detainees or as sentenced prisoners and in a majority of countries, prison populations are increasing. Correction and rehabilitation of the prisoners must be the priority of human dignity. The human dignity itself invites us to provide educational opportunities to prisoners. Educated prisoners are less likely to return to prison. Therefore, various human rights concerns and governmental institutions approach towards the prisoners' rehabilitation through education and proper training.

\subsection{Conclusion}

International community has gifted us a number of positive provisions in various international documents in order to make betterment for the prisoners. Countries are getting involved with the documents as per their own choice and capability to implement the directions therein. When a country becomes signatory of a particular instrument, it becomes mandatory to follow the provisions of that particular instrument by that country. The signatory states are duty bound to implement the provisions of concerned international instrument and to rearrange the provisions of municipal laws and regulations in consistent with those provisions.

\section{Right of Prisoners in the National Instruments}

\subsection{Introduction}

Bangladesh is a member of the United Nations and conforms and supports most of the international instruments regarding human rights and especially the rights of the prisoners. Bangladesh is duty-bound to follow and implement the provisions of such international documents in its national level to its utmost capabilities.

\subsection{The Constitution of Bangladesh}

The Constitution of Bangladesh is the principal safeguard ensuring fundamental human rights of the citizens of Bangladesh. The Constitution provides specific guidelines on how to deal and treat the prisoners. The provisions of the rights guaranteed in the Constitution are fundamental in the sense that the rights are protected and the violation of such tends to the legal remedy through the courts of law.

Albeit the fundamental rights of the Constitution are guaranteed by itself, the rights are subject to law and reasonable restriction. The rights are not absolute and lawful; constraints can be imposed over those rights. However, the rights are applicable beyond any discrimination irrespective of sex, race, caste, religion, colour, place of birth and so on.

Part 3 of the Constitution specifically deals with the fundamental rights. Article 27 provides the principle of equality as below:

"All citizens are equal before law and are entitled to equal protection of law."

The provision does ensure not only the principle of equality among the citizens but also confirms equal legal protection. Equal legal protection is the very basic right for the citizens and the prisoners as well which is very important for their welfare.

An explanatory definition of equal legal protection comes in Article 31. It states:

"To enjoy the protection of the law, and to be treated in accordance with law, and only in accordance with law, is the inalienable right of every citizen, wherever he may be, and of every other person for the time being within Bangladesh, and in particular no action detrimental to the life, liberty, body, reputation or property of any person shall be taken except in accordance with law."

Article 32 adds, "No person shall be deprived of life or personal liberty save in accordance with law."

Article 33 provides the mandatory guidelines on arrest and detention of the persons. The provisions are usually called the principles of fair trial. It categorically says, "(1) No person who is arrested shall be detained in custody without being informed, as soon as may be, of the grounds for such arrest, nor shall he be denied the right to consult and be defended by a legal practitioner of his choice. 
(2) Every person who is arrested and detained in custody shall be produced before the nearest magistrate within a period of twenty four hours of such arrest, excluding the time necessary for the journey from the place of arrest to the Court of the magistrate, and no such person shall be detained in custody beyond the said period without the authority of a magistrate.

(3) Nothing in clauses (1) and (2) shall apply to any person(a) who for the time being is an enemy alien; or

(b) who is arrested or detained under any law providing for preventive detention.

(4) No law providing for preventive detention shall authorise the detention of a person for a period exceeding six months unless an Advisory Board consisting of three persons, of whom two shall be persons who are, or have been, or are qualified to be appointed as, Judges of the Supreme Court and the other shall be a person who is a senior officer in the service of the Republic, has, after affording him an opportunity of being heard in person, reported before the expiration of the said period of six months that there is, in its opinion, sufficient cause for such detention.

(5) When any person is detained in pursuance of an order made under any law providing for preventive detention, the authority making the order shall, as soon as may be, communicate to such person the grounds on which the order has been made, and shall afford him the earliest opportunity of making a representation against the order:

Provided that the authority making any such order may refuse to disclose facts which such authority considers to be against the public interest to disclose.

(6) Parliament may by law prescribe the procedure to be followed by an Advisory Board in an inquiry under clause (4)."

Forced labour of any kind is prohibited except for the following persons, according to Article 34 who are undergoing lawful punishment for a criminal offence.

Protection in respect of trial and punishment is guaranteed in Article 35 which provides:

"(1) No person shall be convicted of any offence except for violation of a law in force at the time of the commission of the act charged as an offence, nor be subjected to a penalty greater than, or different from, that which might have been inflicted under the law in force at the time of the commission of the offence. (2) No person shall be prosecuted and punished for the same offence more than once.

(3) Every person accused of a criminal offence shall have the right to a speedy and public trial by an independent and impartial Court or tribunal established by law. (4) No person accused of any offence shall be compelled to be a witness against himself. (5) No person shall be subjected to torture or to cruel, inhuman, or degrading punishment or treatment."

Among the fundamental human rights guaranteed by the Constitution of Bangladesh the right to fair trial is one of the most important of them. Every individual should enjoy the facility of getting justice irrespective of their sex, race, colour, place of birth and so on.

\subsection{The Prisons Act}

The prison system of Bangladesh is essentially based on the British Prison model. The following Acts and Regulations regulate the establishment and management of jails, the confinements and treatments of person therein, and maintenance or discipline amongst them:

The Prisons Act, No. IX of 1894, as amended

The Prisoners Act, No. V of 1871, as amended

The Prisoners Act, No. V of 1900, as amended

Regulation No III of 1818 (Bengal Code) for the confinement of State Prisoners

International Journal of Educational Studies Vol. 1, No. 2, pp. 26-70

2018

DOI: $10.53935 / 2641-533 x . v 1 i 2.19$

Corresponding Author: Abdul Hamid

Email: mahannan.law@ru.ac.bd

Funding: This study received no specific

Funding: This study received no specific

financial support.

Article History:

Revised: 29 October 2018

Accepted: 22 November 2018

Published: 19 December 2018

(C) 2018 by the authors; licensee Academic

Publishing Group

39
In addition to the above Acts the provisions of the Code of Civil Procedure (Act V of 1908), ${ }^{26}$ the Code of Criminal Procedure (Act V of 1898 as amended), ${ }^{27}$ and the Penal Code (Act XLV of 1860), ${ }^{28}$

\footnotetext{
${ }^{26}$ Hereinafter referred to as the CPC

${ }^{27}$ Hereinafter referred to as the Cr.P.C.

${ }^{28}$ Hereinafter referred to as the PC
} 


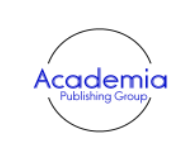

International Journal of Educational Studies Vol. 1, No. 2, pp. 26-70

2018

DOI: 10.53935/2641-533x.v1i2.19

Corresponding Author: Abdul Hamid

Email: mahannan.law@ruac.bd

Funding:This study received no specific

Funding: This study received no specific
financial support.

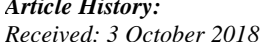

Received: 3 October 2018

Revised: 29 October 2018

Accepted: 22 November 2018

Published: 19 December 2018

() 2018 by the authors; licensee Academic

Publishing Group

40 which relate to the confinement of prisoners, the execution of sentences, appeals, lunatics and the like, are also applicable with regard to prison administration. ${ }^{29}$

The Prisons Act, 1894 popularly known as Jail Code or Bengal Jail Code was legislated by the British rulers with provisions for severe punitive treatment with prisoners and primarily to serve their political purpose. In this Act, Prison is defined as "any jail or place used permanently or temporarily under the general or special orders of the Government for detention of prisoners and includes all lands, buildings, apartments thereto". ${ }^{30}$

According to the provision of the Bengal Jail Code no male officer shall enter to any female prisoners ward unless he has a duty to attend there. The provision in this regard is as follows:

No male officer of the jail shall on any pretext enter the female prisoners enclosure alone or unless he has a duty to attend to there. If a male officer has to attend to any duty in the female enclosure and there is a paid matron or female warder he may enter the females enclosure in her company, and shall be accompanied by her to whatever part of the female jail he may have to go: if the matron is a convict he shall be accompanied by a head warder, and the two shall not separate whilst in the female enclosures at night, the head warder on duty shall call the jailer and these two officers together shall enter the enclosure, warders acting as escorts to official visitors must remain outside the enclosure while prisoners are being inspected. ${ }^{31}$

According to the provisions of the Jail Code the female prisoners shall have the separate facilities in jail custody. The female shall be kept in a ward which will be completely distinct or separated from the male prisoners. The under-trial female prisoners, if possible, be kept apart from the female convicted prisoners. All the activities in this regard shall be conducted by the jailer in the female enclosure. In this regard specific provisions of the Jail Code exists which is as follows:

Female prisoners shall be rigidly secluded from the male prisoners and under trial females shall be if possible be kept apart from the convicts. The female ward shall be so situated as not to be overlooked by any part of the male jail: and there shall be separate hospital for sick female prisoners within or directly adjoining female enclosure. They shall not be required to attend at the jail office. All enquiries and verifications of their warrants shall be conducted by the jailer in the female enclosure. ${ }^{32}$

One of the provisions of the Jail Code regarding torture on the female prisoners is as follows:

In the female division of every jail, there shall be a block of cells sufficient in number for use as punishment cells and to afford separate accommodation for female under trial prisoners. A female under-trial prisoner may at the option of the superintendent if cell accommodation is available have to choose of occupying a cell in the female enclosure instead of being confined in the under-trial prisoners in rule 945 regarding the guarding cells in the female ward and the custody of the keys of these cells can be made. ${ }^{33}$

Provisions have also been included in the Jail Code for the protection of female prisoners from any kind of harassment which may be conducted by the male member of the jail authority. The keys of the female division shall be under custody of paid matron or female warder during day time and at night under the custody of the jailer and the key shall remain in her custody until required next morning for the opening of the female ward. ${ }^{34}$

According to the provisions of the Bengal Jail Code, the female prisoners shall have the right to proper dress, supply of wearing apparels during different seasons of the whole year. Rule 1159 of the Code prescribes the wearing apparels applicable criminal prisoners of division-III categories and who are convicted

\author{
${ }^{29}$ Bengal Jail Code 1894, Chapter I \\ ${ }^{30}$ The Prisons Act, 1894 (Act No. IX of 1894), Section 3 \\ ${ }^{31}$ The Bengal Jail Code, Rule 950 \\ ${ }^{32}$ The Bengal Jail Code, Rule 945 \\ ${ }^{33}$ The Bengal Jail Code, Rule 946 \\ ${ }^{34}$ The Bengal Jail Code, Rule 952
}


rigorous punishment. ${ }^{35}$ Again, for the prisoners fallen into division II with rigorous imprisonment the rule 1165 provides the clothing. ${ }^{36}$

According to the provisions of the Jail Code every female prisoner has the right to association. Loneliness is intolerable and it is the cause of instrumental pain, it may lead a woman to mental disorder. For this reason there is specific provision is in the Jail Code regarding this matter which is as follows:

When there is only one female prison in the female ward and there is no female warder, the superintendent shall arrange to allow a female friend to visit the prisoners and live with her in the jail. If no friend to stay with her, the superintendent shall entertain a female as an extra warder to keep her company in anticipation of the inspector general's (IG Prison) sanctions. ${ }^{37}$

The matter of privacy is not to be neglected. In the female prison provisions regarding privacy should be strictly followed. This is a constitutional right of the female prisoners in Bangladesh. In Bangladesh, in respect of this matter there are specific provisions in the constitution. In the constitution it is said that, "Every citizen shall have the right, subject to any reasonable restriction imposed by law in the interests of the security of the state, public order, public morality or public health

a. to be secured in his home against entry search and seizure and

b. to the privacy of his correspondence and other means of communications". ${ }^{38}$

The Prisons Act 1894 provides that whenever the Superintendent of Jail considers it necessary for the safe custody of prisoners, they might be confined in irons; they might be subjected to secure rules and instructions as ordered by the IG Prison with the sanction of the government to confine them. ${ }^{39}$

\subsection{Conclusion}

When women and children of the country get various development opportunities for their development and empowerment, jails have been kept totally out of this development equation. ${ }^{40}$ So, for the utmost and massive development of the country, the condition of the prisons should be improved. The prisoners should be treated as a member of whole human community. Otherwise a considerable portion of the total population will remain away from the light of human rights. It is a matter of hope that, the government in the recent years has been paying more attention about the condition of jail inmates and thinking of making some reformation in this regard.

\section{Impact of Human Rights Provisions in the Life of the Prisoners \\ 5.1. International Perspectives}

In international arena, the movement for prisoners' rights is based on the principle that prisoners, even though they are deprived of liberty, are still entitled to basic human rights. Advocates for prisoners' rights argue that they are often deprived of very basic human rights, with the unhealthy collaboration of the prison authorities. Alleged violations often include:

- Prison authorities turn a blind eye to assault or rape of prisoners, fail to take sufficient steps to protect prisoners from assault or rape, or even allegedly arrange for prisoners to be assaulted or raped by other inmates as a form of punishment

- Provide insufficient treatment for serious medical conditions

- Refuse freedom of expression, to read materials, and communicate (particularly in cases of foreign languages in prison)

- Punish prisoners who raise complaints about bad conditions

- Take away prisoners' rights to sue prison officials or governments for maltreatment, or to receive compensation for injuries caused by the negligence of prison authorities.

International Journal of Educational Studies Vol. 1, No. 2, pp. 26-70

2018

DOI: 10.53935/2641-533x.vIi2.19

"Corresponding Author: Abdul Hamid

Email: mahannan.law@ru.ac.bd Funding: This study received no specific Funding: This study received no specific financial support.

Article History:
Received: 3 October 2018

Received: 3 October 2018

Accepted: 22 November 2018

Published: 19 December 2018

(C) 2018 by the authors; licensee Academic

Publishing Group

41
- Deprive inmates of freedom of religion.

\footnotetext{
${ }^{35}$ The Bengal Jail Code, Rule 1159

${ }^{36}$ The Bengal Jail Code, Rule 1165, A list of dress of women prisoners is given in the appendix

${ }^{37}$ The Bengal Jail Code, Rule 948

${ }^{38}$ The Constitution of Bangladesh, Article 43

${ }^{39}$ The Prisons Act 1894, Section 56

${ }^{40}$ The Daily Star, Dhaka (Bangladesh), 25 August 2002
} 


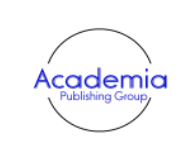

International Journal of Educational Studies Vol. 1, No. 2, pp. 26-70 2018

DOI: $10.53935 / 2641-533 x . v 1 i 2.19$

Corresponding Author: Abdul Hamid Email: mahannanlaw@ruac.bd Funding:This study received no specific Funding: This study received no specific financial support.

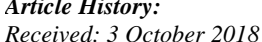

Received. 3 October 2018

Revised: 29 October 2018

Accepted: 22 November 2018

Published: 19 December 2018

(C) 2018 by the authors; licensee Academic Publishing Group

42
- Blockade inmates' rights to legal materials and access to the courts.

- Supply insufficient food and improper clothing to the prisoner.

As a corollary to the above, the following list represents a part of a prisoner's rights:

- Right to be protected by authorities in the case of assault or rape

- Right to medical treatment

- $\quad$ Right to freedom of expression, reading materials, and communication

- $\quad$ Right to express concern with the prison's standard of living

- Right to a legal remedies with regards to prison authorities

- Right to freedom of religion

- $\quad$ Right to access to a court of law (mentioned above)

- Right to drink safe water and get treated as same as everyone else

- $\quad$ Right to food and clothing

Some in the prisoners' rights movement also advocate:

- Conjugal visitation

- Education for inmates

- Increasing the wages for workers who are employed within prisons

A prisoners' rights organisation namely, Preservation of the Rights of Prisoners (PROP) set up in the mid 1970s in United Kingdom to organised more than one hundred prison demonstrations, strikes and protests. PROP was launched on 11 May 1972 in a public house named the Prince Arthur opposite Pentonville Prison, formed to "preserve, protect and to extend the rights of prisoners and ex-prisoners and to assist in their rehabilitation and re-integration into society, so as to bring about a reduction in crime". ${ }^{41}$

PROP's foundation meeting was held in Hull and was attended by 60 people. Speakers included Norwegian sociologist Thomas Mathiesen, Jack Ashwell local branch Secretary of the Transport and General Workers Union (TGWU) and Ros Kane from Radical Alternatives to Prison. ${ }^{42}$

Prisoners' rights are limited. For the most part, jail and prison inmates may demand only a 'minimal civilized measure of shelter'. ${ }^{43}$ Generally, courts follow three basic principles when deciding whether to recognize a particular right. First, an inmate necessarily gives up many rights and privileges enjoyed by the rest of society; second, an inmate does not relinquish all constitutional rights upon placement in prison; and third, the constitutional rights retained by the prison inmate must be balanced against the security concerns of the prison.

The established and recognized rights of prison inmates include freedom of speech and religion; freedom from arbitrary punishment (i.e., restraints, solitary confinement) on the sole basis of beliefs, religion, or racial and ethnic origin; freedom from constant physical restraints; a space for physical movement; essentials for personal hygiene and opportunity to wash; clean bedding; adequate clothing; adequate heating, cooling, ventilation, and light; and adequate nutrition.

Prisoners' rights can be infringed for security purposes. Prisoners have the right to freedom of speech, but prison officials may search their mail, deny a wide variety of reading materials, and edit the content of prison newspapers. Prisoners have the right to adequate space, but they may be confined in isolation for long periods, even years. Prisoners have the right to freedom from restraints, but their ankles and wrists may be shackled when they are moved. They may also be temporarily strapped down or otherwise restrained if officials believe that they present a danger.

Prisoners retain some rights aside from those concerning living conditions. Most prisons 'classify' prisoners and place them in various units according to the categories. For example, violent criminals and persons suspected of gang affiliations are often housed in high-security areas of prison, separate from the remaining prison population. When an inmate is reclassified, he or she is entitled to notice of the reclassification and a citation of reasons for the move.

In USA, Congress and most States authorize the allowance of 'good time' for prison inmates. Good time is credit for time served on good behaviour, and it is used to reduce sentence length. For example, an inmate

\footnotetext{
${ }^{41}$ Fitzgerald, M. (1977) Prisoners in Revolt, Harmondsworth: Penguin, 136-137

${ }^{42}$ Fitzgerald, M. (1977) Prisoners in Revolt, Harmondsworth: Penguin, 142-143; www.tgwu.org.uk/ the official site of the second largest union in the UK

${ }^{43}$ Union County Jail Inmates vs. DiBuono, 713 F.2d 984 [3d Cir. 1983]
} 
may receive one day of good time credit for every three days that he behaves well. Other states withhold recognition of good behaviour until the defendant has served a certain portion of the minimum sentence imposed by the court. In New Hampshire, for example, an inmate may be released for good behaviour after serving two-thirds of the minimum sentence. ${ }^{44}$ When an inmate has good time credits taken away, she or he is entitled to notice, a hearing before the prison board, and an opportunity to present evidence in her or his favour.

Inmates may also gain early release from prison through parole, which is granted by the parole board. Prisoners have no right to parole, and the matter of early release is left to the graces of the parole board. Once released on parole, a parolee may be returned to prison for breaking one of many conditions that are normally imposed. A parolee has no right to an attorney at a parole revocation hearing, nor does an inmate have the right to an attorney at a parole hearing.

Solitary confinement is used in many prisons for violent inmates and those inmates perceived as having gang-related affiliations. Some prisons are designed specifically for it. The original prisons, as envisioned by the Quakers, called for solitary confinement, but the practice was halted because of the detrimental effects it had on prisoners. However, the practice never completely ended. In the 1980s, solitary confinement became a regular feature of prisons, and it has become the sole form of incarceration in so-called Security Housing Units or Supermax prisons.

In a Supermax prison, the cells are eight-by-ten feet and windowless. The cells are grouped in 'pods'. The cell doors are perforated with holes large enough for guards to see inside the cell, but small enough to obstruct the prisoner's vision and light. All a prisoner can see through the door is another white wall. Each cell is furnished with a built-in bunk with a toilet-sink unit. Nothing is allowed on the walls. Prisoners may be allowed television, radio, and books, but these are taken away as punishment for any rule infractions.

Prisoners in solitary confinement are kept in their cells, under surveillance, for $22 \frac{1}{2} 2$ hours a day. Unlike the rest of the prison population, inmates in solitary confinement may not take advantage of educational or recreational programs. The 90 minutes outside the cell may be divided between visiting a small library, washing, and exercising in a pen connected to the pod. Prisoners are strip-searched by the guards before and after visiting any place and are placed in waist restraints and handcuffs when being escorted.

The assignment of a prisoner to solitary confinement is made by prison officials. With regard to assigning supposed gang members to solitary confinement, it is the policy in some prisons to require that the perceived gang member 'debrief' officials on his or her gang activity and renounce his or her gang affiliations before being released back into the general population.

\subsection{National Perspectives}

Bangladesh, an independent country, having a constitution ensuring and protecting fundamental rights of its citizens, has almost miserable prison conditions. Here, prisoners' rights are mostly disregarded in practice, despite detailed legal safeguards, with most persons incarcerated in unsafe, overcrowded cells with inadequate ventilation or sanitation.

Reportedly, the number of prisoners in November 2006 was 66,778, two and a half times in excess of the total capacity. Among them, the number of women prisoners was 2,219 against a capacity of $1,131 .{ }^{45}$ Continued reports of children being held in jails, as well as of foreign prisoners being detained even beyond the expiry of their sentences, and of persons with mental illness being imprisoned for prolonged periods, as well as under trial prisoners lacking legal aid resulted in repeated directives from the High Court Division following public interest litigation by human rights organizations, but a few action was taken to address these issues or release the persons affected.

Widespread torture of detainees is common in criminal investigations in Bangladesh in all regimes, and has become an unmistakable feature of the government's crackdown against independent and political voices. Persons detained by police are routinely subjected to physical and psychological abuse, often from the initial moments of their arrest. The concerned authority often refuses to hold police and security forces accountable for acts of torture, and even tacitly encourages torture through its broadcasting of political prisoners' public 'confessions' as tools of political propaganda. Instituting legal and judicial reform to halt torture, and ending

\footnotetext{
${ }^{44}$ N.H. Rev. Stat. Ann. § 651-A:12 [1983]

${ }^{45}$ Ain O' Shalish Kendro, Human Rights in Bangladesh 2005, Dhaka, 2006
}

Vol. 1, No. 2, pp. 26-70

Correspong35/2641-533x.v1i2.19 Email: mahannan.law@ru.ac.bd Funding: This study received no specific financial support.

Received: 3 October 2018

Revised: 29 October 2018

Accepted: 22 November 2018

() 2018 by the authors; licensee Academi Publishing Group

43 
impunity for it, should be a matter of priority for the government of Bangladesh and for all parties interested in human rights and the security and stability of the region.

Mounting numbers of torture and deaths in pre-and post-conviction detention facilities over the past three decades attest to the brutality of the treatment meted out against detainees and prisoners. Although the Constitution of Bangladesh prohibits torture, few law enforcement officers are held accountable for it.

While the innocent are languishing inside jail for the lack of legal aid, the criminals are enjoying freedom by influencing the criminal justice system. The criminal justice system today is a big business and affects large number of people. The criminal justice system is linked with key socio-political objectives, such as the maintenance of law and order and preservation of the peace, the security of the individual and the protection of property; and, increasingly, the protection of human rights and individual freedoms.

The Bangladesh Penal Code is drafted in accordance with colonial British law, which contains many conflicting and competing policies when applied to present-day situations. The paradox of that law is that it insists on the application of force and the violent deprivation of liberty, consistent with the British colonial perspective, in the name of limiting force and fraud and defending liberty.

The simple fact that prisoners are human beings is often lost sight of. The oblivion of their human identity is not unusual, rather a primitive legacy, which a society like ours can hardly overcome. State incumbents are not sufficiently judicious and cordial to formulate a civilized policy to treat the prisoners a bit humanely. The attitude towards the commoners, at the same time, is not humanitarian enough to furnish them with all basic necessities and civic amenities, so that they may enjoy a human life. This type of common perception constitutes an attitudinal paradigm of the whole society. In most of the developed countries there is a shift from deterrent, retributive, and preventive to reformative approach. Their penal policy and prison system have been structured on the reformative attitude, to give the offenders an opportunity to rectify themselves. In this context our penal policy and prison system lag behind in UN standard.

The zamindars and sultans of Bengal used to detain their enemies in forts and dungeons. The Afghan rulers built a fort at Chawk Bazar, which was later on used as central jail of Dhaka. The English rebuilt the fort in the mid-nineteenth century to accommodate prisoners and they started to use it as a jail from 1798. Initially it had one criminal ward. Today, there are 81 jails, among which 9 are central jails, 56 District jails, and 16 are thana jails across the country. ${ }^{46}$ According to a statistics of the first week of September, 2001, there were total of 68,405 prisoners in the jails of Bangladesh. Among the prisoners 15,865 were convicts, 47,430 were awaiting trial and 1,203 were detained under the Special Powers Act, $1974 .{ }^{47}$ Unfortunately some prisoners' (awaiting trial) term of punishment was less than the period they had spent in jail. ${ }^{48}$

Central jails accommodate convicted prisoners whereas other jails house under-trial prisoners. Overcrowding is the most acute problem encountered by the inmates, and it goes, usually, to such an extent the total number of inmates is almost three times the total accommodation of the jails. Another statistics of 2001 revealed that all the jails of Bangladesh can accommodate a maximum number of 24,152 inmates in total. But the jails have to house 68,408 inmates, almost three times the total capacity. ${ }^{49}$

Prisoners have to sleep in shifts at night because of the overcrowded situation of the jails. Jail Code allocates a space of 36 square feet for every prisoner, but prisoners hardly get the space mentioned. The Daily Janakantha in 2000 revealed that each inmate had only one square ft. of standing space in Nowgaon Jail, let alone space for sleeping. ${ }^{50}$ Condition of Chittagong Central Jail in the same year is most deplorable as 200 inmates were made to use a single toilet and water was rationed to one mug per inmate per day. ${ }^{51}$

Prisoners are served with so low quality of food that they fall sick after consuming those foods. Chronic blood dysentery has been a common disease of the prisoners in all the Jails of Bangladesh. Almost all of them suffer from malnutrition, obviously inadequate quantity of food being the reason. The overall condition has negative impact on the health and hygiene of the prisoners. Most of the jail authorities in Bangladesh failed to fulfil Minimum Standard Rules set by the UN. They failed to ensure minimum floor space, lighting, heating,

46 http://www.thedailystar.net/law/2004/09/02/index.htm

47 Ibid

48 Ibid.

49 Ibid

${ }^{50}$ The Daily Janakantha, Dhaka (Bangladesh), 26 April 2000

51 Ibid. 
and ventilation inside the prisons. Because of the low quality food, inadequate water supply, unhygienic toilet, and damp environment inmates suffer from various diseases like indigestion, diarrhea, dysentery, and skin disease. The attached hospitals of the jails do not have sufficient medical facilities, sometimes seriously ill patients have died due to lack of transport facilities when they are brought from jail to the hospital.

Corruption has become a common phenomenon of all the Jails of Bangladesh. The food, clothing etc. allocated to every prisoner do not reach in their hands due to the misappropriation of the prison authority. They create artificial scarcity and turn prisoners' right and basic needs into rare commodities, which one can buy with cash payment. If anyone visits prison, he/she will find inadequacy of food, and other necessary elements, but financially capable prisoners enjoy all types of facilities remaining incarcerated within the boundary of the prison. All types of narcotics and deadly weapons are available within the prison and rich and influential prisoners can buy them in exchange for cash payment.

Every year more than hundred people die because of various diseases, and lack of proper treatment. 30 convicted prisoners and 87 detainees died in 2002, and 73 convicted prisoners and 37 detainees died in $2003 .^{52}$ A human life cannot be compensated in exchange of anything, whereas every year more than hundred lives fall into the jaws of death, posing a question mark against our growing democracy.

Because of this unfortunate and avoidable death and terrible sufferings, the prisoners often revolt against the prison authority. After the establishment of Bangladesh, from 1976 to date the prisoners revolted 25 times against the prison authority. Prisoners want to be purged of abnormal death and sufferings. They want the Minimum Standard Rules should be implemented and the civic amenities required to sustain as a human being should be ensured for every prisoner.

When any individual is put within the bars of the prison, it does not mean that he/she lost his/her identity. They have been deprived of their valuable right, freedom of movement. So long s/he possesses human identity he/she has the right to have all the basic necessities and civic amenities ensured by the Constitution and also by the Standard Minimum Rules of UN. The under-trial prisoners and prisoners awaiting trial in no way should be subjected to deprivation of basic citizen's rights. Even the convicted prisoners cannot be deprived of their right to food, clothing, health, hygiene, and medication. If their basic necessities are not sufficiently fulfilled, that becomes brutal embodiment of hell on this earth. Incarcerating convicts within the four boundaries of the prison without basic necessities of the prisoners are as good as rigorous punishment for them.

While conditions of living vary from jail to jail, standards in most of the 67 Bangladeshi prisons are appallingly low. Prisons are beleaguered by severe overcrowding, degenerating material infrastructure, absence of adequate medical care, incidences of sentry brutality and fraud, and prisoner-on-prisoner cruelty. Non-existence of pressure groups, indifferent attitude of lawmakers and bureaucrats, and inattention of public media keep the public unaware of the pervasive conditions inside the prisons. The governments have been completely aloof and apathetic to the dismal human rights violations in our prisons. There are virtually no efforts and programs towards remedying these conditions and abuses in the immediate future.

The prison statistics say that Bangladesh currently has 60 prisoners for every 100,000 of its population. Pre-trial detainees/remand prisoners are about two-thirds of the total prison population. A total of 623 death penalty awardees are waiting to be executed in different cells. ${ }^{53}$

In 2004, Bangladesh had a capacity of holding 28,394 prisoners in all its prisons. With 83,136 inmates in these prisons, the occupancy ratio is 292 per cent. ${ }^{54}$ Overcrowding is obviously more acute in Dhaka Central Jail, as with a capacity of 2,682 inmates, it currently occupied by 11,014 prisoners. This is 410 per cent of the prescribed habitation. The other 66 prisons outside Dhaka have a current occupancy ratio of 280 per cent, where 72,122 people are living in a space for 25,712 people ${ }^{55}$ For the prisoners ordained to die, there are 61 cells in the country. The occupancy ratio of these cells is 14 per cell in Dhaka, and 10 per similar cells in the country's other prisons.

A very predictable result of overcrowding, malnutrition, unhygienic conditions, and absence of medical

International Journal of Educational Studies Vol. 1, No. 2, pp. 26-70

2018

DOI: $10.53935 / 2641-533 x . v 1 i 2.19$

Corresponding Author: Abdul Hamid Email: mahannan.law@ruac.bd Funding: This study received no specific

Funding: This stidy

Article History:
Received: 3 October 2018

Received: 3 October 2018

Revised: 29 October 2018

Accepted: 22 November 2018

Published: 19 December 2018

(C) 2018 by the authors; licensee Academic

Publishing Group

45 care is the spread of contagious diseases, often leading to premature disability and deaths in prisons. Recently,
${ }^{52}$ Ibid
${ }^{53} \mathrm{http}: / /$ www.thedailystar.net/2004/06/13/d40613150295.htm
${ }^{54} \mathrm{Ibid}$
${ }^{55} \mathrm{Ibid}$ 
Tuberculosis continues to devastate prison populations around the world, and there is no reason why its havoc should be any different in Bangladesh. Sick inmates carrying virulent pathogens, infect other new prisoners, and constitute a serious threat to public health when they are released. It is important to keep a prisoner with a contagious disease in quarantine, or in a separate cell. Lawmakers should introduce a bill to allow inmates in the late stages of terminal illnesses to return home to their families.

The practice of corporal punishment on the prisoners is common in Bangladesh; leg irons, fetters, shackles, and chains are characteristically used. The weighty bar irons used in Bangladeshi prisons turn simple daily movements into agonizing ordeals. Physical maltreatment of prisoners by guards remains as a chronic complexity in Bangladesh. In most prisons, unnecessary beatings are so common as to be an essential part of prison life.

In 1997, a report of BRCT states that, 26 persons died in police and jail custody, out of whom 23 died in jail custody or under treatment of jail authority, and 3 in police custody, 3 people lost their life by police torture. Besides, 28 persons were killed and 174 were injured by police, BDR and ANSAR firing. 11 women were raped by members of the law enforcement agencies. The actual figure is more than this because the unmarried girls and housewives do not report the incidents of rape for fear of losing their prestige. ${ }^{56}$

There are sufficient and good provisions in the Jail Code for female prisoners for their safety. But the reality is totally different. The condition of female in our country is getting worse day by day. They are quite unsafe either in the jail custody or outside the prison or even in the police custody. There are number of reasons behind these circumstances. Most of the female prisoners are harassed and tortured both physically and mentally by different Law Enforcement Authorities (LEA).

The female prisoners in Bangladesh have to undergo mental torture as they are treated in ill-manner by the members of the jail authority. The members of the jail authority constantly violate their duties imposed by the Jail Code upon them. They often harass the female prisoners in form of severe mental torture.

Female prisoners made up 1.6 per cent of total prison population in $1998 .^{57}$ Women prisoners are for the most part exposed to custodial sexual abuse. The problem is widespread in Bangladesh, where male guards and inmates can easily overpower female inmates.

There are 1,063 children in 60 jails, and 280 more in the correction centres in Bangladesh. In infringement of international standards, juvenile inmates are often held together with adults. Many of Bangladesh's jails and police lock-ups mix juvenile and adult prisoners. Children in such circumstances frequently fall victim to bodily abuse, including sodomy by adult inmates.

Violence is common at the prisons. Inmate-on-inmate violence is an unsurprising result of official slackness. By neglecting to take charge of the inmates within their facilities, by failing to act in response to incidences of violence, by wickedly allowing the entry of armaments into the prisons, and by generally abetting the domination of the strongest prisoners over the weakest, prison authorities are directly liable for the violence.

Extortion by prison staff and corruption of the guards is common. Given the extensive power that prison guards exercise over inmates, these problems are obvious. The poorly paid guards try to complement their regular earnings by exploiting the prisoners as bait for their friends and relatives. In exchange for smuggled goods or special attention and treatment, inmates supplement guards' salaries with bribes. Powerful and rich inmates often enjoy rich diets and comfortable lodgings, while their less opportune brethren live in nastiness. It is alleged that some criminals, in collaboration with the prisons guards, keep on operating and networking their gang activities outside while being locked up inside the prisons.

In order to get the actual state of human rights in the jail an interview was made with the following under trial prisoners who had been in the Rajshahi Central Jail for a long period. ${ }^{58}$ Their bail petitions were rejected several times. ${ }^{59}$

\begin{tabular}{llll}
\hline Name of the prisoner & Age & $\begin{array}{l}\text { Duration in the } \\
\text { Jail }\end{array}$ & $\begin{array}{l}\text { Number of times the bail } \\
\text { petition are refused }\end{array}$ \\
\hline
\end{tabular}

\footnotetext{
56 Annual Report of BRCT, 1997

57 Ibid

${ }^{58}$ Interviews have been made with the Prisoners in the Rajshahi Central Jail and in the Rajshahi Sessions Court while the Prisoners were produced in the court. Interviews have also been made with the prisoners in Kushtia, Pabna, Comilla and Chittagong, the findings was similar and therefore this interview reflects the jail situation of Bangladesh.

59 See the Questionnaire Form in Appendix VIII
} 


\begin{tabular}{llll}
\hline 1. Joyenuddin & 30 & 14 months & 8 \\
2. Ruhul Amin & 35 & 18 months & 15 \\
3. Atoar Rahman & 40 & 12 months & 20 \\
$\begin{array}{l}\text { 4. Sohrab Hossain } \\
\text { 5. Abul Kalam Azad, }\end{array}$ & 32 & 27 months & 20 \\
$\quad$ Father-SamidulHaque & 28 & 14 months & 19 \\
6. Abul Kalam Azad & 32 & & \\
7. Golam Mortoza & 28 & 27 months & 20 \\
$\begin{array}{l}\text { 8. Md. Alal Uddin } \\
\text { 9. M.Tarab Ali }\end{array}$ & 26 & 7 months & 3 \\
10. Md.Ashraful Alam & 42 & 2 months & 3 \\
11. Md.Abdul Mannan & 35 & 4 months & 5 \\
12. Md.Sayedur Rahman & 32 & 12 months & 12 \\
\hline
\end{tabular}

All of the above prisoners complained that the standard of food is very low and space is very small. They also reported that their bail petitions were rejected by the courts several times and they lead a very inhuman life in the jails.

The victims of prison injustice, particularly those who were poor and helpless and could not afford legal representation; have not been protected against torture and harassment. A victim of custodial torture can move the court directly through writ petition for protection of his fundamental rights, specially the right to life and liberty guaranteed by the Constitution though it is very expensive.

In Bangladesh prisoners are confined without recreational and educational opportunities. In recent years the prisoners in some cells started only to get electric fans. The government has given televisions to the prisoners in Dhaka Central Jail and 30 other prisons, and is planning to provide fans and televisions to the prisoners in other jails. Fiscal constraint, among others, is also to blame for prison deficiencies in Bangladesh. The age-old physical structures of most of the prisons are dilapidated.

Knowing about the current capacity-constraints, the government has decided to shift Dhaka Central Jail to Keraniganj. Whereas under-trial prisoners should be kept near to where their cases will be heard, prisoners serving long tenures, and those with a repeated crime history should better be moved to a distant location in a maximum security prison. A sparsely populated small island in the Bay of Bengal can be chosen, and such a prison can be set there. The government may decide to choose any of the following islands - Char Kukuri Mukuri, Burir Char, Neta, Andar Char, or Bhaylabania, to establish the first Maximum Security Prison in Bangladesh.

\subsection{State of Emergency}

Certain human rights have been curtailed under the emergency regulations. There is concern particularly about freedom of media and freedom of expression, assembly and association. International law permits derogations or restrictions on these rights during a state of emergency but puts very stringent restrictions on such derogations.

Amnesty International believes that some of the restrictions imposed through the Emergency Powers Rules (EPRs) exceed what is permissible under international law in the current situation in Bangladesh. Amnesty International believes that the current rules and restrictions on freedom of expression, assembly and association are too widely framed and are being selectively applied, creating uncertainty and fear.

Amnesty International has protested against the arrest and prosecution of some teachers of Rajshahi and Dhaka University in 2007. Amnesty International considered the Rajshahi University teachers to have been prisoners of conscience. Amnesty International considers the four Dhaka University teachers to be prisoners of conscience and calls for their immediate and unconditional release.

We call on the Government to urgently review and amend the restrictions on rights to freedom of expression, assembly and association invoked under the state of emergency. We believe such amendments should be a first step towards the lifting of the state of emergency. A state of emergency is by nature temporary and, therefore, should not be used as a long-term mode of governance.

\section{In particular \\ National Human Rights Commission (NHRC)}


Amnesty International urges the Caretaker Government (CTG) in 2007 to ensure that the National Human Rights Commission (NHRC) is set up in accordance with international principles, which require it to be independent of the government; diverse in membership; to have a broad mandate, adequate powers of investigation and adequate resources. Its mandate must also include investigation of abuses by armed forces and security officials.

There should be a clear timeline for making the NHRC operational and transparent. There should also be an inclusive process for selecting the membership. The leadership of the NHRC will be critical to its survival and therefore places a particular responsibility on the government to ensure that it is properly done.

\section{Judiciary}

The CTG has taken significant and welcome steps in separating the judiciary from the executive. Yet guaranteeing the independence of the judiciary requires more than the separation of the executive from the judiciary. They must ensure that judicial appointments are made on merit, that security of tenure is properly assured and that patterns of political patronage and interference are broken.

\section{Police reform}

Effective policing requires the support of local communities, yet public mistrust in the police is pervasive and cannot be restored unless there is professional, competent and effective police reform. That is a long-term endeavour. But there are some key initiatives that the CTG can begin. As well as the preparation of a draft Police Ordinance, Amnesty International would also encourage it to consider an independent police complaints mechanism to bring about accountability to the police system and give it operational independence from the executive to carry out its functions without political interference.

\section{Freedom of information}

Amnesty International welcomes the commitment made by the Caretaker Government to pass legislation on the right to information. In Bangladesh, where extreme poverty and lack of access to basic services are widespread, the right to information is potentially of great significance to some of the most vulnerable and marginalized groups.

However, the benefits of the proposed law will only be forthcoming if the law is in line with international standards, is well-established by appropriate mechanisms and resources, and if people are made aware of it. Amnesty International therefore urges the CTG to make the draft law widely available for consultation.

\subsection{Conclusion}

Bangladeshi prison officials and guards need to be educated and trained to treat prisoners with due respect for their intrinsic self-respect and value them as human beings. Prejudice on the basis of race, sex, religion, political or other opinion, and national or social origin must be done away with. Prisoners should be allowed to practice their religious rituals. All prisoners should have the right to take part in cultural activities and education directed to the full advancement of human potential. Policy formulations are needed to enable prisoners to undertake meaningful wage-earning jobs inside the prisons, which will allow them to contribute to their own financial support and to that of their immediate family members, and facilitate their reintegration into the country's labour market when they come out after serving their time. Prisoners must have the right of entry to the health services available in the country without unfairness on the standing of their legal status.

Failure to improve the living conditions in Bangladesh prisons may lead to extreme anguish among the prisoners, and may direct them to take violent public attention drawing activities, like hunger strikes, selfmutilation, rioting, and other forms of dissent. Three years ago, in Kazakhstan, 44 inmates at a prison attempted mass suicide in protest of conditions. The inmates used razors and broken glass to hack their necks.

International Journal of Educational Studies Vol. 1, No. 2, pp. 26-70

2018

DOI: $10.53935 / 2641-533 x . v 1 i 2.19$

Corresponding Author: Abdul Hamid

Email: mahannan.law@ru.ac.bd Funding: This study received no specific

Funding: This stidy

Article History:
Received: 3 October 2018

Revised: 29 October 2018

Accepted: 22 November 2018

Published: 19 December 2018

(C) 2018 by the authors; licensee Academic

Publishing Group

| 48 
6. Initiatives Taken By the Government for the Prisoners

6.1. Introduction

The police are alleged of bribe, the army is incorporate with mass corruption, the BDR mutinied and drive brutal killings, the judges are influenced by political pressure and favour or diverted by some means are the common scenario of Bangladesh.

While the innocent are languishing inside jail for lack of legal aid, the criminals are enjoying freedom by influencing the criminal justice system. The criminal justice system today is a big business and affects large number of people. The criminal justice system is linked with key socio-political objectives, such as the maintenance of law and order and preservation of the peace, the security of the individual and the protection of property; and, increasingly, the protection of human rights and individual freedoms.

\subsection{Through the Ministry Of Social Welfare}

Ministry of Social Welfare, Bangladesh plays the most vital role regarding betterment of the prisoners of Bangladesh. It started many facilities for the prisoners. It, though having certain obstacles, attempts to take steps towards the rehabilitation of the prisoners through a number of programmes which include necessary training and education in order to make the prisoners as human resources when they will come out from their concerned prisons. The education for the prisoners include basic education and religious and moral education. They are given certain vocational training so that they may change their lives in a positive way after completion of their sentence. However, the initiatives are not enough and satisfactory. This is high time to take effective measures for the suggested welfare of the prisoners.

Due to rapid industrialisation, urbanisation and change in the social attitude, the number of juvenile (engaged in minor criminal activities) have increased to a great extent. There are several causes which usually help to engage a child in criminal activities. Important among the causes are poverty, absence in primary education, unrest and quarrel in family, divorce, easy availability of drugs and arms, etc. To combat child criminality and correct their character, several programmes have been undertaken by the Ministry of Social Welfare in the late nineteen seventies.

\subsubsection{The Juvenile Development Centres}

The Juvenile Development Centres take the responsibility of caring, protecting, providing food, housing, clothing, medicare, education, vocational training and correctional and human development, counselling to the committed children. These are done as per the provisions of the Children's Act, 1974, the National Children Policy and in accordance with the provisions of the UN Convention on the Rights of the Child (CRC), 1989.

The objective of the Juvenile Centre is to create a congenial atmosphere in the family and also in the society by giving due attention to all dimensions of protection, survival and development of the children who are in contact with law. The Government has given due attention to consider the special needs of the juvenile offenders in terms of ethical and human rights. A Juvenile Development Centre extends its every effort to eliminate adverse effects which make children delinquent through recognised methods of correction.

The specific objectives of the Juvenile Development Centres are:

1. To receive the juveniles in the Juvenile Development Centre for correction, not for the punishment

2. To carry out the judgment imposed by the courts with utmost humanity

3. To retain the rights and privileges like other members of the society

4. To assist the rehabilitation and integration of the Juvenile offenders into the community as law abiding and productive citizen of the country

5. To give importance to the family and society in the correctional process.

International Journal of Educational Studies Vol. 1, No. 2, pp. 26-70

2018

DOI: $10.53935 / 2641-533 x . v 1 i 2.19$

Corresponding Author: Abdul Hamid

Email: mahannan.law@ru.ac.bd Funding: This study received no specific financial support.

Article History:

Received: 3 October 2018

Revised: 29 October 2018

Accepted: 22 November 2018

Published: 19 December 2018

(C) 2018 by the authors; licensee Academic

Publishing Group

49
Juvenile delinquency has emerged as a matter of concern in Bangladesh in recent times with the number of mostly poor children involved in criminal activities. Numerous social factors coupled with poor parenting, family troubles and above all poverty pushes these children to undesirable activities.

There are two exclusive Acts in Bangladesh to deal with the Administration of Juvenile Justice. These are-The Children Act, 1974 and the Probation of Offenders Ordinance, 1960 (amended in 1964).

The Government initiatives for meaningful and effective operation of these Acts have been intensified and taken with all seriousness in recent times. The Government has so far established three Juvenile Development 
Centres under the provision of the Children Act, 1974, each of which consists of one Juvenile Court, one Remand Home and one Training Institute.

These centres are:

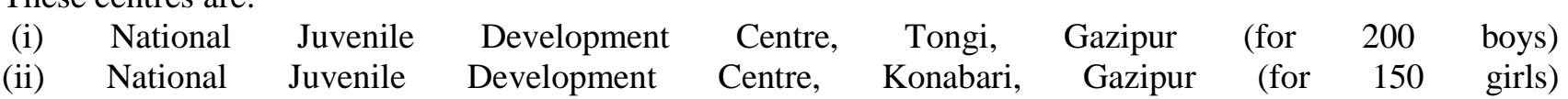

(iii) Juvenile Development Centre, Jessore (for 150 boys )

Another Juvenile Development Centre (with capacity of 300) having similar programmes/components is going to be established at Joypurhat District. Necessary facilities of the existing two units located at Tongi and Jessore would be increased for the accommodation of additional 350 inmates. In total the number of inmates of these 4 centres would be 1150 . A total number of 12446 juveniles have been rehabilitated through this programme up to June $2008 .^{60}$

There is a remand home in every Juvenile Development Centre. The Remand Home of the Juvenile Development Centre does not bear traditional meaning and purpose. Actually, it is used as the safe home for care, custody, protection and observation of delinquent children remanded by any Court awaiting trial. As per section 20 of the Children Act of 1974, the Government may establish and maintain remand homes for detention, diagnosis and classification of children committed to custody by any Court or Police. Through the Remand Home of the Juvenile Development Centre a separate custodial arrangement is made for the younger offenders during their under trial period. The objective of the separation of the youthful offenders from the adult and serious prisoner is to protect them from their bad influence, abuse and harassment in the normal prison. The Remand Home while detaining the children for trial and custody offers physical security, child friendly environment and healthy living condition to the children. This special arrangement of detention provides opportunities for close observation and study of the children's individuality taking into account, child psychology, socio-economic background, abilities and aptitudes of child recorded by the Probation Officer, Social Case Worker and any other Officer assigned for diagnosis of the juvenile delinquents. On the basis of observation and study, a social inquiry report (pre-sentence report) is prepared and produced at the trial Court. This report helps the Court to pass an order about the child concerned. This report also helps the Correctional Officers to develop treatment plan for the children in contact with law. Ultimately, this diagnosis helps children in their correction and reintegration in the society.

\subsubsection{The Training Institute}

The Training Institute is a centre for training, education, behavioural correction and development of the children sent by juvenile court or other courts of the country. This Institute also provides facilities for skilldevelopment training in suitable trades, compulsory primary education and counselling services for correction and human resource development. Thus huge number of derailed juveniles has been educated, trained and rehabilitated in the society and thereby helping the Government in reducing criminal activities as well as in creating favourable environment to live on. Majority of the juveniles have returned to their normal life and engaged them in the socio-economic activities. ${ }^{61}$

Through these centres about 15800 Juvenile delinquents have been given accommodation along with other facilities and out of these about 11399 juveniles have been corrected, rehabilitated and provided legal aid support. ${ }^{62}$

\subsection{Conclusion}

This is better to observe that the provisions regarding welfare of the prisoners in Bangladesh are satisfactory albeit not sufficient. Statutes like the Children Act, 1974 is a masterpiece in relation to the proper management of the children in Bangladesh who involved with courts and jail. The Children Act was formed far before the formation of CRC. Provision of keeping children in the 'certified institutes' unlike the majors in jail is a very good sign.

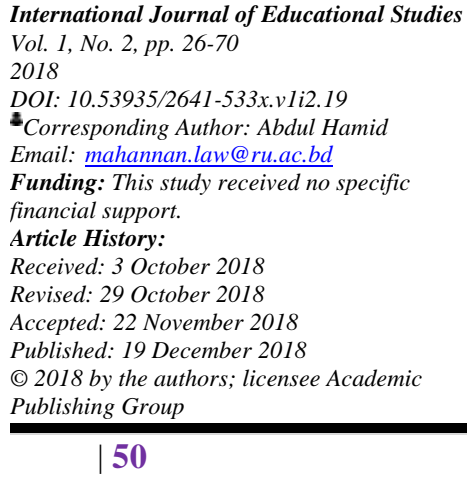

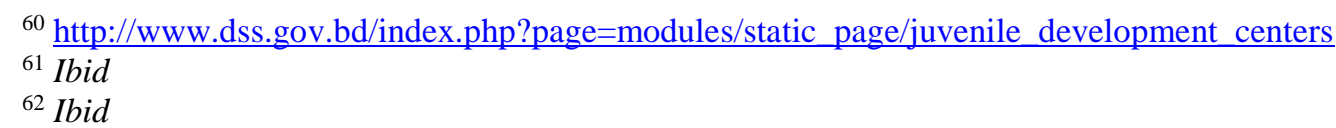




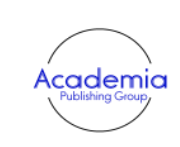

International Journal of Educational Studies Vol. 1, No. 2, pp. 26-70 2018

DOI: 10.53935/2641-533x.v1i2.19

Corresponding Author: Abdul Hamid Email: mahannan.law@ru.ac.bd Funding: This study received no specific Funding: This study

Article History:
Received: 3 October 2018

Received: 3 October 2018

Accepted: 22 November 2018

Published: 19 December 2018

() 2018 by the authors; licensee Academic Publishing Group

51
However, the statutes concerning the rehabilitation of the prisoners through education and necessary training are not satisfactory. They should be updated and revised. The actors should pressurize the government to incorporate the provisions or create new regulations as early as practicable.

Usually in the prisons of Bangladesh the prisoners, according to the existing prison rules, are being involved in various intra prison activities. Principally those are as follows:

1. Gardening is one of the major activities of the prisoners who are sentenced for rigorous imprisonment.

2. Cooking is another job that the prisoners learn and perform. They cook in canteen and dining. When they become free after the completion of prison period, they are reintegrated in the mainstream social economic activities.

3. Interested prisoners are taught various arts and handicrafts. The women prisoners can contribute in the state economy performing in the home small economies when they become freed.

4. Teaching in different fields such as understanding holy books, the prisoners may develop their mentality and social approach in a better morale.

The other alternative or supplementary works the prison authorities may initiate are as below:

1. In a special arrangement to the prisoners, the prisoners may be involved in mass education and technical teaching outside the prison areas. The department of social welfare of the government may supervise the whole process in association with the home department.

2. The learners may teach other new prisoners who are not educated. This method of teaching may be highly effective if properly monitored.

3. Concerned NGOs may be offered to train prisoners of Bangladesh on IT skills and vocational training for meaningful employment so that the prisoners make themselves employable when they return to society.

\section{Constraints and Limitations}

\subsection{Introduction}

Although existing laws of our criminal justice delivery system are well formed, those on the treatment of the prisoners are not satisfactory. Whatever we want to do for the betterment of the prisoners or the government attempts, necessary laws and regulations are needed. Statutes have enforceability. But we don't have such statutes. On the other hand, whatever we have in our laws, proper implementation is not done. For that reason, the problem exists and the prisoners do not get developed.

\subsection{Legal Framework Constraint}

For decades, successive governments in Bangladesh have failed to curb serious human rights violations arising from the use of legislation and widespread practices in the law-enforcement and justice system which violate international human rights standards. These violations include torture, deaths in custody; arbitrary detention of government opponents and others; excessive use of force leading at times to extra-judicial executions; death penalty; sporadic attacks against members of minority groups; and acts of violence against women.

\subsubsection{Arbitrary Detention, Undermining the Judicial System}

Each year, thousands of people are arbitrarily detained under administrative detention laws, which deny them access to judicial remedies. The most commonly used of these laws is the Special Powers Act (SPA), 1974.

In practice, when the government invokes the SPA, it is invariably to detain members of opposition parties. When district magistrates invokes the Act, it is usually to secure detention of someone whose release whether or not on bail - would, in their opinion, cause the commission of a "prejudicial act".

Although the SPA gives a wide discretion to the detaining authority to act according to its own opinion, in practice, most detention orders are declared unlawful by the Supreme Court only on procedural grounds. This is because the Constitution empowers the High Court Division of the Supreme Court to satisfy itself that a person is detained in custody under a lawful authority. Calls for the repeal of the SPA have come from the Bangladeshi legal community and human rights organisations. It has also come from political parties but only when they are in opposition. When in government, they have defended the use of the SPA and maintained it. 


\subsubsection{Torture in Bangladesh}

For many years, torture has been the most widespread and persistent human rights violation in Bangladesh but has been routinely ignored by successive governments since Bangladesh's independence in 1971.

Children, women, the elderly, opposition politicians, criminal suspects, and innocent bystanders in the streets, have all been victims of torture. Perpetrators are most often police personnel but members of the armed forces carrying out law enforcement duties have also been involved in torture.

Methods of torture have included beating with rifle butts, iron rods, bamboo sticks, or bottles filled with hot water so they do not leave marks on the body, hanging by the hands, rape, 'water treatment' in which hose pipes are fixed into each nostril and taps turned on full for two minutes at a time, the use of pliers to crush fingers, and electric shocks.

Successive governments in Bangladesh have failed to prevent torture, despite provisions in the Constitution of Bangladesh and their obligation to provide durable and effective protection against torture to the people in the country under treaties which Bangladesh has ratified.

Impunity is one of the major reasons why torture continues. Government authorities have persistently failed to bring perpetrators of torture to justice. Allegations of torture are rarely investigated, particularly when victims are members of opposition parties. On rare occasions when allegations of torture have been investigated, this has usually been due to a public outcry generated by the death of the victim. In other cases, victims who have filed complaints about torture in police custody have been put under pressure to withdraw the case. This has most often been done by threats and intimidation, but in some instances, money has been offered to the victim in return for the withdrawal of the case as 'out of court settlement'.

Furthermore, judicial proceedings against a public employee including a police officer can proceed only if the government authorises that proceeding. In practice, the government rarely does so.

\subsubsection{Concerning use of Section 54 of the Cr. P. C.}

Establish clear and enforceable safeguards against abuse of Section 54 of the Cr.P.C. and other administrative detention procedures resulting in torture. Magistrates do not ignore safeguards against unlawful detention when ordering a prisoner's remand into police custody; to that effect, ensure that the prisoners are physically produced before the magistrates when police request a prisoner's remand into custody, and ensure that the magistrates actively take steps to ascertain whether or not the detainee has been tortured, taking care not to prejudice the detainee's safety, for example, by asking questions in the presence of the detaining police officers.

It is the duty of government to investigate every allegation of torture through an impartial and independent inquiry to identify perpetrators of torture according to international standards. Ensure that all perpetrators of torture and those whose negligence has facilitated torture are brought to justice without delay. For decades, successive governments in Bangladesh have failed to curb serious human rights violations arising from the use of legislation and widespread practices in the law-enforcement and justice system which violate international human rights standards. These violations include torture, death in custody; arbitrary detention of government opponents and others; excessive use of force leading at times to extra-judicial executions; death penalty; sporadic attacks against members of minority groups; and acts of violence against women.

\subsection{Financial Constrains}

Fundamental Rights depend on socio-economic condition of any state. Fundamental rights which are adopted in the Constitution of Bangladesh mostly depend on the socio-economic condition of the country. Prison conditions are extremely poor for the majority of the prison population. One Human Rights organization reported that 72 people died in prison or police custody during the year 2009. Another report of Ain O' Shalish Kendra (ASK) revealed that most of the deaths were reported to have been caused by sickness. It was frequently reported that genuine sick detainees are often not admitted in the jail hospital, because payment of a bribe enables another influential detainee, who may not have been sick, to enjoy the moderately better and less cramped accommodation in a jail hospital for several months. It may be concluded that the provisions pertaining to a sick prisoner under Sections 741 and 742 of the Jail Code are ignored. ${ }^{63}$ According

${ }^{63}$ Das JA, 'Condition of Prison and Rights of Prisoners', in Human Rights in Bangladesh 2001, Ain O' Salish Kendra (ASK), Dhaka: 2002 
to credible sources, poor conditions were at least a contributing factor in many of these deaths. Most prisons are overcrowded and lack adequate facilities. Government figures indicate that the existing prison population of roughly 66,550 is 278 per cent of the official prison capacity. ${ }^{64}$

Of those, approximately 25 per cent of those detained had been convicted and 71 per cent were awaiting trial or under trial. In some cases, cells are so crowded that prisoners sleep in shifts. The Dhaka Central Jail reportedly houses more than 9,775 prisoners in a facility designed for fewer than 3,000 people. ${ }^{65}$ A judicial report in 1998 noted that the physical condition of jails is poor; foods are not hygienically prepared and drugs are abused widely inside the prisons.

The treatment of prisoners in the jails is not equal. There are three classes of cells: A, B, and C. Common criminals and low-level political workers generally are held in C cells. Bangladesh, Country Information often has dirt floors, no furnishings, and poor quality food. The use of restraining devices on prisoners in these cells is common. Conditions in A and B cells are markedly better; A cells are reserved for prominent prisoners.

A new prison facility in Kashimpur, north of Dhaka, opened in September 2008. In general the government does not permit prison visits by independent human rights monitors. Government-appointed committees of prominent private citizens in each prison locality to monitor prisons monthly, but do not release their findings. District judges occasionally also visit prisons, but rarely disclose their findings.

\subsection{Conclusion}

Bangladesh is one of the least developed countries in the world. Basic necessities for its citizens are yet to be ensured. Although free and compulsory primary education is one of the fundamental principles of our State policy, primary education for every child is not implemented here. Education and vocational training programmes for the prisoners and detainees require excessive finance that we don't have. Due to financial restraints, our prisons do not have sufficient infrastructure.

\section{Interviews with Different Officials and Prisoners}

\subsection{Introduction}

243 persons $^{66}$ of several police stations of 8 districts namely, Dhaka, Rajshahi, Chittagong, Barisal, Comilla, Jessore, Kushtia, Jhenaidah and Faridpur were interviewed from the lists received from police stations on random basis on different aspects of violation of human rights. We received information from them regarding the nature of violation of human rights including the treatment they received from the executives under police or jail custody or during remand. Besides, 16 lawyers, 52 judicial officers and 54 Police Officers were interviewed in order to obtain their opinion regarding the state of human rights in Bangladesh. The study reveals that human rights have been and are being violated by the executives in the banner of black law like the Special Powers Act, 1974 or under the coverage of antihuman provisions of different Codes prevalent in Bangladesh. Illegal detention under the Special Powers Act and misuse of Sections 54 and 167 of the Cr. P. C. contribute to a large extent in violating human rights in the country. This has been shown in a tabular form:

\subsection{Interviews with Victims}

Victims of violation of human rights both by the Law Enforcing Agencies (LEA) and by others are interviewed. The following table shows the percentage of violation of human rights by LEA and others.

\author{
${ }^{64}$ Ibid. \\ ${ }^{65} \mathrm{Ibid}$. \\ 66 Political persons 03, Teachers 08, Advocates 01, Students 112, Businessman 56, Service holder 14, Unemployed \\ persons 09, Farmer 25, Labour 13, Hawker 01 and Beggar 01
}


8.2.1. Table No. 1

\begin{tabular}{ccll}
\hline $\begin{array}{c}\text { Victim of violation of } \\
\text { human rights by LEA }\end{array}$ & $\begin{array}{c}\text { Victim of violation of } \\
\text { human rights by others }\end{array}$ & $\begin{array}{l}\text { Not } \\
\text { responding }\end{array}$ & Total \\
$222(93.27 \%)$ & $16(6.72 \%)$ & 5 & 243 \\
& & & $(100 \%)$ \\
\hline
\end{tabular}

243 persons have been interviewed of whom 222 persons became the victim of violation of human rights by the LEA like police, jail authority; 16 persons became the victim of such violation by persons other than LEA and 5 persons did not answer in this respect.

\subsubsection{Table No. 1(1)}

Violation has been divided into two categories, physical and mental. Table shows these two types of violation:

\begin{tabular}{lll}
\hline Physical torture & Mental torture & Total \\
$147(66.21)$ & $75(33.78)$ & $222(100 \%)$ \\
\hline
\end{tabular}

222 persons were interviewed of them 147 persons were physically tortured and 75 persons were tortured mentally.

\subsubsection{Tables No. 1(2)}

The following table shows the place where human rights have been violated.

\begin{tabular}{llll}
\hline Jail & Police & Both jail and police & Total \\
custody & custody & custody & \\
$48(21.6$ & $168(75.67$ & $6(2.70 \%)$ & $222(100$ \\
$2 \%)$ & $\%)$ & & $\%)$ \\
\hline
\end{tabular}

It has been stated earlier that violation of human rights under jail and police custody sometimes led to death of the victims.

\subsubsection{Violation of Human Rights under SPA and Others Laws}

8.2.2.1. Table No. 2(1)

Out of 243 persons 225 persons detained/arrested under the SPA and by other laws shown in the following table.

\begin{tabular}{|c|c|c|c|c|}
\hline Under the SPA & By other laws & $\begin{array}{l}\text { Sub- } \\
\text { total }\end{array}$ & $\begin{array}{l}\text { Not } \\
\text { applicable }\end{array}$ & Total \\
\hline $73(32.44 \%)$ & $152(67.55 \%)$ & $225(100 \%)$ & 18 & 243 \\
\hline
\end{tabular}

Out of 243 persons interviewed 73 persons were detained under the SPA, 152 persons were kept in custody in the jail and 18 persons do not fall under any category.

\subsubsection{Table No. 2(2)}

Period of detention under the SPA

\begin{tabular}{cccccc}
\hline 30 day & 30 days to & 120 days & 121 days to & More than & Total \\
& 90 days & & 180 days & 180 days & \\
16 & 19 & 16 & 13 & 09 & 73 \\
\hline
\end{tabular}

International Journal of Educational Studies Vol. 1, No. 2, pp. 26-70

2018

DOI: 10.53935/2641-533x.v1i2.19

Corresponding Author: Abdul Hamid

Email: mahannan.law@ru.ac.bd

Funding: This study received no specific

financial support.

Article History:

Received: 3 October 2018

Revised: 29 October 2018

Accepted: 22 November 2018

Published: 19 December 2018

( 2018 by the authors; licensee Academic

Publishing Group

\section{4}

Out of 243 persons who were interviewed 73 persons were detained by the SPA. 16 persons were detained for 30 days, 19 persons were detained up to 90 days, 16 persons were detained up to 120 days, 13 persons were detained up to 180 days and 9 persons were detained from 240 days up to a maximum period of 34 months. 
8.2.3. Table No. 3

Arrested persons taken under remand and otherwise.

\begin{tabular}{|c|c|c|c|c|}
\hline Remanded & Without remand & Sub-total & $\begin{array}{l}\text { Not } \\
\text { applicable }\end{array}$ & Total \\
\hline $88(39.11 \%)$ & $\begin{array}{l}137 \\
(60.88 \%)\end{array}$ & $225(100 \%)$ & 18 & 243 \\
\hline
\end{tabular}

Out of 243 persons interviewed 88 persons were granted remand by the Magistrate, which is, $39.11 \%$ and 137 persons were not taken into remand which is $60.88 \%$. Rest of the 18 persons do not fall in any category.

\subsubsection{Table No. 4}

This table shows how the persons detained/arrested tried to get relief from torture by giving bribe to the police authority or by using political influence during remand.

\begin{tabular}{cccc}
\hline Bribe given & Political influence used & Not applicable & Total \\
$52(60 \%)$ & $05(5.68 \%)$ & 31 & $88(100 \%)$ \\
\hline
\end{tabular}

The above table shows that 88 persons were taken into remand under Section 167 of the Cr. P. C. out of 243 persons interviewed. $60 \%$ of the remanded persons were forced to pay bribe to the police authority and $5.68 \%$ used political influence in order to get relief from physical and mental torture. This shows the nature of violation of human rights during remand, although there is constitutional bar against torture either during remand or otherwise.

Statement given by one of the 88 accused arrested is stated herein below to reveal the nature of torture by police under their custody.

Moulana Motahar Hossain, a local College teacher of Rajshahi City, was arrested by Boalia thana police under Rajshahi district while performing maghrib prayer at Hatemkhan Mosque on 14 June 1997. In the police station he was beaten mercilessly by 4 police personnel by turn. He was kicked by boot and hit by helmet on his head. He was not supplied with water to quench his thirst, though later on it was given. On 15 June he was taken in a small room where his eyes were blind folded. Thereafter he was given electric shock and in consequence he lost sense. He was then sent to Rajshahi Central Jail where he became seriously ill due to electric shock and physical torture. His hearts was affected so he was sent to Rajshahi Medical College Hospital in cardiology ward from where he was sent to Dhaka PG Hospital when his condition further deteriorated. He was then confined for 39 days in jail where he was not given proper diet, kept under bar fetter (Dandaberi). Bail petition was refused several times. But ultimately he was granted bail by Sessions' Judge Court after 38 days.

Another victim, Sarwar Kamal, a student of Law Department of Rajshahi University, was arrested twice by Motihar thana police under Rajshahi district without warrant. He was first arrested on 25 November 1997 and for the second time on 13 February 1998 from Sher-E-Bangla Hall, Rajshahi University. He stated in the interview that both the times he was tortured physically by the police of Motihar thana as a part of their routine work and as a result of such torture one of his ankle was fractured. He was also taken into remand for 4 days where he was both physically and mentally tortured. He was not given cloth to cover his body to protect from cold, though it was winter and he fell ill. But no medical care was given. He was then sent to Rajshahi Central Jail where he was kept confined for three months. There he received inadequate food, inadequate space to sleep and inhuman behaviour from the jail authority, as he did not give any bribe to them for release.

M Isharat Ali, an under trial prisoner was in Pabna district Jail for 3 months and 15 days from December 1994 to March 1995. He was a businessman who held the position of Upazila Chairman of Atgharia under Pabna district. His bail hearing was delayed for a long time for political rivalry. He said that the meal of the jail, the condition of the room and the process of meeting with the relatives were not satisfactory. He added that the behaviour of the prison police was not good. He had to stay in a small room with another 50 to 60 prisoners. Due to this congestion he could hardly sleep peacefully. At last he was granted bail and later he was acquitted from the case.

Of the 243 persons interviewed, $98 \%$ replied that there were no lawful grounds for their detention/arrest. 
8.2.5. Table No. 5

Violation of human rights under jail custody:

\begin{tabular}{lcc}
\hline Victim of violation of human rights & $\begin{array}{l}\text { No Victim of violation of } \\
\text { human rights }\end{array}$ & Total \\
$210(46.41 \%)$ & $33(13.58)$ & $243(100 \%)$ \\
\hline
\end{tabular}

Table shows that $46.41 \%$ prisoners are the victims of violation of human rights.

\subsubsection{Table No. 6}

Statistics of bail granted by different courts

\begin{tabular}{lllcl}
\hline Magistrate & Sessions & High Court Divisions & Bail rejected & Total \\
Courts & Court & of Supreme Court & & \\
115 & 90 & $49(15.56 \%)$ & 10 & 264 \\
$(4356 \%)$ & $(34 \%)$ & & $(3.78 \%)$ & $(100 \%)$ \\
\hline
\end{tabular}

Of 243 persons, 21 persons were arrested more than one and as such the total number has become $264(243+21)$. Table shows that $43.56 \%$ arrested persons were granted bail by Magistrate Courts, $34 \%$ by sessions courts, $18.56 \%$ by High Court Division of Supreme Court and 3.78\% (10 arrested) were not granted bail up to the time when they were interviewed. It is to be noted that the bail petition of most of the arrested persons were rejected several times even in some cases it was rejected for thirty times.

\subsection{Interviews with Lawyers}

16 lawyers from different bar of Bangladesh were interviewed regarding the causes of violation of human rights. Opinion has been given about preventive detention, its legal foundation and also their concern about the repeal of the SPA and amendment of Section 54 of the Cr. P. C.

\subsubsection{Table No. 7}

Causes of Violation of human rights

\begin{tabular}{|c|c|c|c|c|}
\hline $\begin{array}{l}\text { Absence of proper } \\
\text { application of law } \\
12\end{array}$ & $\begin{array}{l}\text { Misuse of } \\
\text { power } \\
\times\end{array}$ & $\begin{array}{l}\text { Unusual delay in } \\
\text { disposing of suit } \\
\times\end{array}$ & $\begin{array}{l}\text { Abuse of } \\
\text { power by LEA } \\
4(+2)\end{array}$ & $\begin{array}{l}\text { Total } \\
16\end{array}$ \\
\hline
\end{tabular}

Table shows that out of 16 legal practitioners 12 said that the cause of violation of human rights in Bangladesh is the absence of proper execution of law, 4 said that both absence of proper execution of law and abuse of power by LEA are responsible for violation of human rights.

\subsubsection{Table No. 8}

Opinion about preventive detention under the SPA

\begin{tabular}{lrrr}
\hline Inhuman & $\begin{array}{l}\text { Days Violation of } \\
\text { human rights }\end{array}$ & Harassment & Total \\
$5(41.66 \%)$ & $5(41.66 \%)$ & $02(16.66 \%)$ & $12(100 \%)$ \\
\hline
\end{tabular}

$41.66 \%$ said that preventive detention is inhuman, $41.66 \%$ said that it is violation of human rights and $16.66 \%$ that it is nothing but harassment.

\subsubsection{Table No. 10}

Opinion about Preventive Detention under the SPA

International Journal of Educational Studie Vol. 1, No. 2, pp. 26-70

2018

DOI: 10.53935/2641-533x.v1i2.19

Corresponding Author: Abdul Hamid

Email: mahannan.law@ruac.bd

Funding: This study received no specific

financial support.

Article History:

Received: 3 October 2018

Revised: 29 October 2018

Accepted: 22 November 2018

Published: 19 December 2018

( 2018 by the authors; licensee Academic Publishing Group

\section{6}

Inhuman Violation of human rights

$6(41.66 \%)$ $6(41.66 \%)$

$41.66 \%$ said that preventive detention is inhuman, $41.66 \%$ said that it is violation of human rights and $16.66 \%$ that it is nothing but harassment.

\begin{tabular}{ll} 
Harassment & Total \\
$4(16.66 \%)$ & 16 \\
& $(100 \%)$ \\
\hline
\end{tabular}




\subsubsection{Table No. 11}

Legal foundation of torture under remand

Opinion of lawyers about granting remand

\begin{tabular}{ccl}
\hline Legal & No legal foundation & Total \\
$\mathrm{x}$ & $16(100 \%)$ & $16(100 \%)$ \\
\hline
\end{tabular}

$100 \%$ lawyers expressed their opinion against police remand $100 \%$ lawyers also said that confinement of an accused in the jail for an indefinite period due to procedural complicacy is unjustifiable and amounts to violation of human rights.

\subsubsection{Table No. 12}

Opinion regarding amendment or repeal of Sections 54 and 167 of the Cr. P. C. and SPA

\begin{tabular}{lll}
\hline In favour of amendment of Sections 54 & In favour of repeal of & Total \\
and 167 & SPA & \\
$6(41.66 \%)$ & $10(100 \%)$ & $16(100 \%)$ \\
\hline
\end{tabular}

$41.66 \%$ want amendment of Sections 54 and 167 of the Cr. P. C. and $90 \%$ want the repeal of the SPA. Some of them opined that no need to repeal the provisions of these two sections, but there should be proper guidelines and appropriate measures in the application of those provisions.

\subsection{Interviews with Judicial Officers}

Interviewed 52 judicial officers of Rajshahi, Dhaka, Barisal, Faridpur, Khulna, Chittagong, Jessore and Jhenidah in order to get idea regarding the state of human rights of the accused during or in course of trial and also the impacts of Section 54 of Cr. P. C. and SPA upon the accused/detainees or convicts.

\subsubsection{Table No. 13}

Where any accused became the victim of discrimination during trial:

\begin{tabular}{cccl}
\hline $\begin{array}{c}\text { Victim of discrimination } \\
6(11.53 \%)\end{array}$ & No of discrimination & Abstained & Total \\
& $42(80.76 \%)$ & $4(7.69 \%)$ & 52 \\
& & & $(100 \%)$ \\
\hline
\end{tabular}

Out of 52 judicial officers, 6 said that in some cases discrimination takes place, 42 said no discrimination takes place and rest 4 abstained from making any comment.

\subsubsection{Table No. 14}

Comments of the judicial officers regarding amendment of Sections 54 and 167 of the Cr. P. C.

\begin{tabular}{llcc}
\hline $\begin{array}{l}\text { In favour of } \\
\text { amendment }\end{array}$ & $\begin{array}{l}\text { Not in favour } \\
\text { of amendment }\end{array}$ & Abstained & Total \\
$13(25 \%)$ & $34(65.38 \%)$ & $5(9.61 \%)$ & $52(100 \%)$ \\
\hline
\end{tabular}

$25 \%$ is in favour of amendment of Sections 54 and 164 of the Cr. P. C whereas $65.38 \%$ is against amendment of those sections, rest $9.61 \%$ abstained from making any remark.

\subsection{Interviews with Police Officers}

54 Police Officers were interviewed in order to receive their opinion about remand, detention, physical and mental torture of the accused or detainees during remand.

International Journal of Educational Studies Vol. 1, No. 2, pp. 26-70

2018

DOI: 10.53935/2641-533x.v1i2.19

Corresponding Author: Abdul Hamid

Email: mahannan.law@ru.ac.bd

Funding: This study received no specific

financial support.

Article History:

Received: 3 October 2018

Revised: 29 October 2018

Accepted: 22 November 2018

Published: 19 December 2018

(c) 2018 by the authors; licensee Academic

Publishing Group

| 57

\subsubsection{Table No. 15}

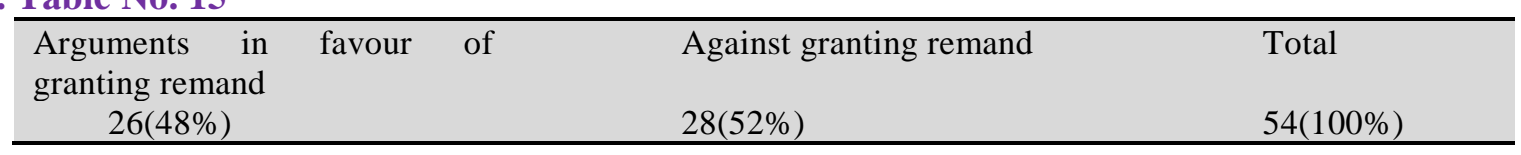

$48 \%$ police officers opined that in order to get information from the accused remand is necessary, whereas $52 \%$ gave opinion against remand. 
8.5.2. Table No. 16

Opinion regarding detention

\begin{tabular}{llllr}
\hline $\begin{array}{l}\text { Justification } \\
\text { detention }\end{array}$ & of & $\begin{array}{l}\text { Against } \\
\text { detention } \\
17(31.48 \%)\end{array}$ & Abstained & Total \\
$34(62.96 \%)$ & & $3(5.55 \%)$ & $54(100 \%)$ \\
\hline
\end{tabular}

34 Police Officer argued in favour of detention whereas 17 argued against detention. 3 Officers abstained from making any comment.

\subsubsection{Table No. 17}

Effects on human rights for delay in disposal of suits

\begin{tabular}{|c|c|c|c|}
\hline $\begin{array}{l}\text { Delay in disposing of suit } \\
\text { amounts to violation of human } \\
\text { rights }\end{array}$ & $\begin{array}{l}\text { Not violation of } \\
\text { human rights }\end{array}$ & Abstained & $\begin{array}{l}\text { Tot } \\
\text { al }\end{array}$ \\
\hline $12(22.22 \%)$ & $34(62.96 \%)$ & $8(14.81 \%)$ & $54(100 \%)$ \\
\hline
\end{tabular}

$22.22 \%$ police officer said that delay in disposing of suit leads to violation of human rights $62.96 \%$ opined that delay does not amount to violation of human rights, $14.81 \%$ abstained from making any comment.

\subsection{Conclusion}

In this study it was attempted to take interview of 50 judicial officers, 50 members of the LEA and 50 Lawyers. But the interview was made of 52 judicial officers, 54 members of LEA and 16 Lawyers. Though the number of Lawyers is not fulfilled to 50 most of them are renowned lawyers of the Supreme Court of Bangladesh having good records on this particular issue and therefore opinion of them consciously reflects the original picture of the matter concerned.

In this empirical study for assessing the actual situation of the human rights of the accused, reliance was made on interviews of the victims or accused along with different personnel mentioned above. Though there exists a dissenting opinion among their views, the study reveals a clear picture of violation of human rights in the country.

Since the provisions of Sections 54 and 167 of the Cr. P. C. and the SPA are the necessary evils in the context of Bangladesh, some of the interviews suggest for repeal whereas some other prescribe for bringing reform in those laws and fair application thereof.

\section{General Conclusion and Recommendation}

Bangladesh is strongly committed to the promotion and protection of all human rights and fundamental freedoms. Its commitment to promoting and protecting human rights flows from the realization that the wellbeing of the people can only be ensured through effective enjoyment of all human rights by all. Bangladesh has been endeavouring to build a society that is free from all forms of exploitation and in which human rights, fundamental freedoms, equality and justice are secured. Bangladesh holds that all human rights are universal, indivisible, interdependent and mutually reinforcing. Some of what Bangladesh neglected to mention in its pledge:

In 2007, the government's human rights record remained a matter of serious concern, in part due to the state of emergency that remained in place for most of the year and the failure to fully investigate extrajudicial killings. The state of emergency, which was relaxed temporarily in advance of local elections in August and finally lifted on December 17, curtailed many fundamental rights, including freedom of expression, freedom of association, and the right to bail. In 2007, the government promulgated the Emergency Powers Rules (EPR) and Emergency Powers Ordinance, 2007 to enforce the state of emergency. The anticorruption drive that the government initiated, while greeted with popular support, gave rise to concerns about fairness and equity under the law. For most of the year the government banned political activities, although this policy was enforced unevenly. There was a decrease in the number of extrajudicial killings by security forces, but they committed serious abuses, including extrajudicial killings, custodial deaths, arbitrary arrest and detention, and harassment of journalists. Some members of security forces acted with impunity and committed acts of 
physical and psychological torture. Violence against women and children remained a serious problem, as did trafficking in persons.

Failure to improve the living conditions in Bangladesh prisons may lead to extreme anguish among the prisoners, and may direct them to take violent public attention drawing activities, like hunger strikes, selfmutilation, rioting, and other forms of dissent. In Kazakhstan, 44 inmates at a prison attempted mass suicide in protest of conditions on 2001. The inmates used razors and broken glass to hack their necks. We do not want analogous incidents to occur in Bangladesh.

Sir Winston Churchill once said that, "the mood and temper of the public in regard to the treatment of crime and criminals is one of the most unfailing tests of the civilisation of any country". We want to invoke another two criteria, together with Churchill's touchstone, to measure the civilised standard of any country. Those are, first, how women and children are treated in a society and second, whether minorities are wellprotected in that society. If we ask ourselves these questions, the answers will not be very satisfactory.

However, we do hope that our government will take effective measures to improve the life of the prisoners. The prisoners who might occur crime and got sentenced for causes of miserable economic condition or for any social perspective, if they get proper education and training in the prison, they may be the human resources when they may released, which will be a great contribution to our national economy and nationhood.

One of the principals of the birth of Bangladesh was to build a land where human rights and rule of law would be established; where progress and development would come through democracy. We have a huge number of populations which became a burden of our economic growth. But we want to alter this population from burden to resources. Prisoners should be well trained so that they can come to the mainstream people's progress. We see the light at the end of the tunnel. It may be too far but our strong determination and goal will reach the light in quicker way.

The need of the hour is an organisational culture that condemns abuse of power and misuse of force and encourages pro people policing. All those who are concerned with the arrest, detention, and custody of the people, particularly of the poor and vulnerable sections of the society, must strictly implement the constitutional and legal protections and safeguards. It is necessary that the guardians of law and the custodians of lock-ups and prison houses should be made aware of the constitutional and legal rights of the people. For Bangladesh, goal oriented judiciary can limit the scope of executive arbitrariness to ensure implementation of its dictations.

The time for the reformation of the criminal justice system of Bangladesh has come. The question is how to achieve a proper balance between the provision of the criminal law and the preservation of liberty and freedom of the individual.

The police are an essential component of the criminal justice system in Bangladesh. The police play a very important and vital role for the implementation of fair trials. The Bangladeshi government is trying to fix the agenda for democratic policing by transforming the police force into a police service with the help of United Nations Development Programme (UNDP).

The prison system has become a vital component of suppression and brutality, even though prison should be a place for rehabilitation and correction. Simply put, justice is detained behind the walls of these Bangladeshi prisons. Prison reform is a necessary objective to ensure people's rights and 'humanize' Bangladesh. Prisoners' rights have become an important item on the agenda for prison reforms. Lawmakers should introduce a bill to humanize the prison system in Bangladesh, where the main philosophy of prison systems is based on colonial law.

Being so closed to the delivery of justice, the criminal justice system of Bangladesh needs wide reforms that demand a revival in the criminal justice system. All past and present governments kept busy fulfilling their own agenda. Reformation ends not in contemplation, but in action.

Prisons are a vital part of many societies. While these workplaces are not for everyone, many people enjoy the opportunity to aid in the rehabilitation of prisoners and the management of prison life. There may many different types of prison jobs that might require a wide variety of different skills.

Case law in Bangladesh in the context of under trial prisoners is nonexistent. In view of the violation of human rights in the jail of Bangladesh the following recommendations are suggested to ameliorate worsening condition of the prisoners.

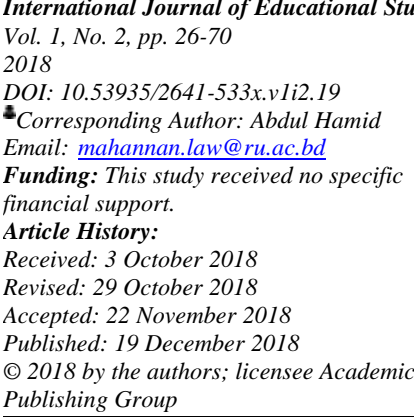


i) The number of jail is to be increased in order to accommodate the prisoners with sufficient space for them to live in.

ii) Proper supervision by the respective Deputy Commissioners and District Judges of concerned districts should be done so that the prisoners can communicate their grievances and on the basis of complaints remedial measures may be taken.

iii) Delay in quick disposal of the case is the most important cause of over-crowdedness in the jail. More courts are to be established with sufficient number of judges so that the under-trial prisoners and detainees may either be convicted or acquitted or released as the case may be. This will reduce the number of inmates of the prisons and the problem of over-crowdedness will be solved to a great extent.

iv) Proper sanitation is to be maintained in order to improve the present unhygienic condition.

v) The quality and quantity of food must be improved.

vi) Medical treatment and medical care are to be ensured.

vii) Reformative arrangement for the convicts and under-trial prisoners may be made to improve their moral character so that after their release they may lead a better life.

viii) Provision may be made for the detainees so that they can file writ petition to their respective district courts instead of writ to High Court Division. This can be done by amending the Constitution.

ix) Besides, punitive measures must be taken against those jail authorities who are responsible for the unnecessary sufferings of the prisoners. Bribe is to be stopped in iron hand. It has been reported in different human rights journals that the prisoners are forced to offer bribe, otherwise they are tortured in different techniques.

In recent years some penologists of India have advocated the need of spiritual training for those who are condemned and incarcerated in prison cells. They shortly believe that the practice of yoga and meditation will enable the prisoners to control the evils of kama, krodha, mada and lobha which dwell in human body and help in gaining control over these evil forces so as to turn him a good man and a good citizen. This is indeed a new approach to penological problem of crime and criminals in the Indian setting. As rightly observed by Mr. Justice Ram Pal Singh of the High Court of Delhi, "human body is a temple where the deity of atma and parmatma reside. For keeping the temple of flesh and blood, the abode of good and bad, the sages and saints have prescribed shadhna by regular practice of yoga, which shall keep the human body not only healthy and strong but also neat, clean and pure. Healthy people would avoid crime and try to do good to the society by establishing peace and tranquillity". ${ }^{67}$ Thus by the practice of yoga in prisons crimes can be considerably controlled and hardened criminals can be reformed. Undoubtedly, the idea is laudable and must be adopted in practice. Inspired by this idea, many state governments of India have made training in yoga compulsory for prison inmates along with religious discourses. ${ }^{68}$ Bangladesh can borrow this idea to reform the prisoners with such practices as are suitable to its society and culture.

From our thorough investigation and analysis we strongly submit the following recommendations:

1. The foremost responsibility towards the development of the prisoners goes to the government. In a welfare state, it is the government who is to look after its citizens. The government should form a separate agency who will supervise the entire conditions of the prisoners in Bangladesh.

2. Such governmental agency should comprise efficient and experienced professionals who will care and monitor the prison conditions effectively.

3. The agency should have reasonable fund to implement necessary measures for the proper education and training programmes for the prisoners. The government should allocate sufficient finance in its annual budget.

4. Such agency will monitor and supervise the prisoners regularly so that the prisoners may become human resources.

International Journal of Educational Studies Vol. 1, No. 2, pp. 26-70

5. The proposed agency will send annual report to the Ministry of Social Welfare on the development of the prisoners.

6. The government should take proper steps to create public consciousness regarding rehabilitation of the prisoners.

\footnotetext{
${ }^{67}$ Rem Pal Singh, 'Yoga and Indian Penology' in Central Indian Law Quarterly Journal, Vol. 1(1987), 92-93

${ }^{68}$ Paranjape NV, Criminology and Penology, (Ninth edition, Central Law Publications, Allahabad: 1996), 269
} 
7. The civil society should come forward to raise its voice in order to pressurize the government towards the protection of the rights of the prisoners. They may arrange seminars, symposiums, talk shows etc. to make the objective effective.

8. Media is so strong in our society now-a-days. It can play a pivotal role in this regard.

9. Government must make effective laws and amend the loopholes of the current laws of the land that is very important to go forward in ensuring rights of the prisoners.

10. Government should consult and follow United Nations Standard Regulations related to the rights of the prisoners and detainees.

11. Government should be sincere to its utmost capabilities to ensure the above recommendations.

12. Non-governmental organizations, national and international, may act and support the proper activities for the betterment of the prisoners.

\section{Bibliography}

Ain O' Salish Kendra

Annual Report of BRCT, 1997

Fitzgerald, M. (1977)

George F. Kneller

Justice Mozammel Haque

M Ershadul Bari

Manjula Batra

Morris B Abram

NV Paranjape

PD Sharma

Sarkar AH

Taylor, I. (1981)
Human Rights in Bangladesh 2005, Dhaka 2006

State of Human Rights, (Published in 1997; Dhaka)

Bangladesh Kishore Aparadher Bichar Babostha O' Shishuder Birudhe Sohingsota Songkranto Borshopunji (The Judicial System of Juvenile Offences and Annual Report regarding Violence against Children in Bangladesh) Save the Children, UK and Odhikar, 2001)

: Prisoners in Revolt, Harmondsworth: Penguin

: Introduction to the Philosophy of Education, (New York: John Wiley and Soni, 1971)

: Human Rights Today-UN Briefing Papers, (UN Publications: October, 1998)

: Illustrated Oxford Dictionary, (Oxford University Press: Dorling Kindersley Limited, 2008)

: 'Human Rights and Rights to liberty: Before and Now', in Human Rights Law, (Dhaka, 1997)

: 'The Universal Declaration of Human Rights-The Magna Carta of Mankinds', in Human Rights in Contemporary International Law, (Dhaka, 1997)

: Protection of Human Rights in Criminal Justice Administration, (Deep \& Deep Publications, New Delhi: 1989)

: 'Freedom of Thought Conscience and Religion', in Journal of the International Commission of Jurists, (1997)

: Criminology and Penology, (Ninth edition, 1966: Central Law Publication, Allahabad, India)

: Police and Criminal Justice Administration in India, (1985)

: Criminology: Theory and Analysis, Kollo Prokashony, Dhaka: 2005

Law and Order: Arguments for Socialism, London: Macmillan

The Bengal Jail Code, 1894

The Constitution of Bangladesh

The Prisons Act, 1894

The Standard Minimum Rules, Sections 37, 40 and 41

Universal Declaration of Human Rights

The Bengal Jail Code, 1894 
http://findarticles.com/p/articles/mi_qa4111/is_200412/ai_n9466371/

http://www.dss.gov.bd/index.php?page=modules/static_page/juvenile_development_centers

http://www.prisonerseducation.org.uk/index.php?id=9

http://www.thedailystar.net/2004/06/13/d40613150295.htm

http://www.thedailystar.net/law/2004/09/02/index.htm

Appendices

I. Relevant Provisions of the Constitution of Bangladesh

II. Relevant Provisions of the Fundamentals of the Code of Criminal Procedure (Cr. P. C.) in Bangladesh

III. Relevant Provisions of the Special Powers Act (SPA) in Bangladesh

IV. Relevant Provisions of the Universal Declaration of Human Rights (UDHR)

V. Relevant Provisions of the International Covenant on Civil and Political Rights (ICCPR)

VI. A list of dress for the Women Prisoners

VII. GLOSSARY

VIII. Questionnaire Forms

\section{APPENDIX I: CONSTITUTION OF BANGLADESH}

\section{Relevant Provisions}

ARTICLE 26: LAWS INCONSISTENT WITH FUNDAMENTAL RIGHTS TO BE VOID

(1) All existing law inconsistent with the provisions of this Part shall, to the extent of such inconsistency, become void on the commencement of this constitution.

(2) The state shall not make any law inconsistent with any provisions of this Part, and any law so made shall, to the extent of such inconsistency, be void.

(3) Nothing in this article shall apply to any amendment of this protection of law.

ARTICLE 27: EQUALITY BEFORE LAW

All citizens are equal before law and are entitled to equal protection of law.

\section{ARTICLE 31: RIGHT TO PROTECTION OF LAW}

To enjoy the protection of the law, and to be treated in accordance with law, and only in accordance with law, is the inalienable right of every citizen, whenever he may be, and of every other person for the time being within Bangladesh, and in particular no action detrimental to the life, liberty, body, reputation or property of any person shall be taken except in accordance with law.

\section{ARTICLE 32: PROTECTION OF RIGHT TO LIFE AND PERSONAL LIBERTY \\ No person shall be derived of life or personal liberty saves in accordance with law.}

\section{ARTICLE 33: SAFEGUARDS AS TO ARREST AND DETENTION}

(1) No person who is arrested shall be detained in custody without being informed, as soon as may be, of the grounds for such arrest, nor shall be denied the right to consult and be defended by a legal practitioner of his choice.

(2) Every person who is arrested and detained in custody shall be produced before the nearest Magistrate within a period of twenty-four hours of such arrest, excluding the time necessary for the journey from the place of arrest to the court of the magistrate, and no such person shall be detained in custody beyond the said period without the authority of a Magistrate.

(3) Nothing in clauses (1) and (2) shall apply to any person-

a) who for the time being is an enemy alien; or

b) who is arrested or detained under any law providing for preventive detention

(4) No law providing for preventive detention shall authorise the detention of a person for a period exceeding six months unless an Advisory Board consisting of three persons, of whom two shall be 


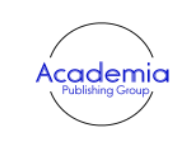

International Journal of Educational Studies Vol. 1, No. 2, pp. 26-70

2018

DOI: 10.53935/2641-533x.v1i2.19

Corresponding Author: Abdul Hamid

Email: mahannan.law@ru.ac.bd

Funding: This study received no specific

financial support.

financial support.

Article History:
Received: 3 October 2018

Revised: 29 October 2018

Accepted: 22 November 2018

Published: 19 December 2018

(C) 2018 by the authors; licensee Academic

Publishing Group

63 persons who are, or have been, or are qualified to be appointed as, Judges of the Supreme Court and the other shall be a person who is a senior officer in the service of the Republic, has, after affording him an opportunity of being heard in person, reported before the expiration of the said period of six months that there is, in its opinion, sufficient cause for such detention.

(5) When any person is detained in pursuance of an order made under any law providing for preventive detention, the authority making the order shall, as soon as may be communicate to such person the grounds on which the order has been made, and shall afford the earliest opportunity of making a representation against the order:

Provided that the authority making any such order may refuse to disclose facts which such authority considers to be against the public interest to disclose.

\section{ARTICLE 43: PROTECTION OF HOME AND CORRESPONDENCE}

Every citizen shall have the right, subject to any reasonable restrictions imposed by law in the interest of the security of the State, public order, public morality or public health-

a) to be secured in his home against entry, search and seizure; and

b) to the privacy of his correspondence and other means of communication.

\section{APPENDIX II: RELEVANT PROVISIONS OF THE FUNDAMENTALS OF THE CODE OF CRIMINAL PROCEDURE (CR.P.C.) IN BANGLADESH}

SECTION 54: WHEN POLICE MAY ARREST WITHOUT WARRANT

Police Officer may, without an order from a Magistrate and without a warrant, arrest-

first of all, any person who has been concerned in any cognisable offence or against whom a reasonable complaint has been made or credible information has been received, or a reasonable suspicion exists of his having been so concerned;

secondly, any person having in his possession without lawful excuse, the burden of proving which excuse shall lie on such person, any implement of housebreaking;

thirdly, any person who has been proclaimed as an offender either under this Code or by order of the Government;

fourthly, any person in whose possession anything is found which may reasonable be suspected to be stolen property, and who may reasonable be suspected of having committed an offence with reference to such thing;

fifthly, any person who obstructs a Police Officer while in the execution of his duty, or who has escaped, or attempts to escape, from lawful custody;

sixthly, any person reasonably suspected of being a deserter from the armed forces of Bangladesh;

seventhly, any person who has been concerned in, or against whom a reasonable complaint has been made or credible information has been received or a reasonable suspicion exists of his having been concerned in, any act committed in Bangladesh, would have been punishable as an offence, and for which he is, under any law relating to extradition or under the Fugitive Offenders Act 1881, or otherwise, liable to be apprehended or detained in custody in Bangladesh;

eighthly, any released convict committing a breach of any rule made under Section 565, Sub-section

ninthly, any person for whose arrest a requisition has been received from another Police Officer, provided that the requisition specified the person to be arrested and the offence or other cause for which the arrest is to be made and it appears therefrom that the person might lawfully be arrested without a warrant by the officer who issued the requisition.

\section{SECTION 167: PROCEDURE WHEN INVESTIGATION CANNOT BE COMPLETED IN TWENTY- FOUR HOURS}

(1) Whenever any person is arrested and detained in custody, and it appears that the investigation cannot be completed within the period of twenty-four hours fixed by Section 61, and there are grounds for believing that the accusation or information is well-founded, the Officer-in-charge of the police 
station of the police Officer making the investigation if he is not below the rank of Sub-inspector shall forthwith transmit to the nearest Magistrate a copy of the entries in the diary hereinafter prescribed relating to the case, and shall at the same time forward the accused to such Magistrate.

(2) The Magistrate to whom an accused person is forwarded under this section may, whether he has or has not jurisdiction to try the case, from time to time, authorise the detention of the accused in such custody as such Magistrate thinks fit, for a term not exceeding fifteen days in the whole. If he has not jurisdiction to try the case or send it for trial, and considers further detention unnecessary, he may order the accused to be forwarded to a Magistrate having such jurisdiction.

Provided that no Magistrate of the third class, and no Magistrate of the second class not specially empowered in this behalf by the Government shall authorise detention in the custody of the police.

(3) A Magistrate authorising under this Section detention in the custody of the police shall record his reasons for so doing.

(4) If such order is given by a Magistrate other than the Chief Metropolitan Magistrate (CMM), District Magistrate (DM) or Sub-divisional Magistrate (SDM), he shall forward a copy of his order, with his reasons for making it, to the Magistrate to whom he is immediately sub-ordinate.

(5) If the investigation is not concluded within one hundred and twenty days from the date of receipt of the information relating to the commission of the offence or the order of the Magistrate for such investigation.

(a) the Magistrate empowered to take cognisance of such offence or making the order for investigation may, if the offence to which the investigation relates is not punishable with death, imprisonment for life or imprisonment exceeding ten years, release the accused on bail to the satisfaction of such Magistrate; and

(b) the Court of Session may, if the offence to which the investigation relates is punishable with death imprisonment for life or imprisonment exceeding ten years, release the accused on bail to the satisfaction of such court;

Provided that if an accused is not released on bail under this sub-section, the Magistrate or, as the case may be, the Court of Session shall record the reasons for it;

Provided further that in cases in which sanction of appropriate authority is required to be obtained under the provisions of the relevant law for prosecution of the accused, the time taken for obtaining such sanction shall be excluded from the period specified in this sub-section

\section{APPENDIX III: RELEVANT PROVISIONS OF THE SPECIAL POWERS ACT (SPA), 1974 IN BANGLADESH}

\section{SECTION 3: POWER TO MAKE ORDER DETAINING OR REMOVING CERTAIN PERSONS}

(2) Any District Magistrate or Additional District Magistrate may if satisfied with respect to any person that with a view to preventing him from doing any prejudicial act within the meaning of Section 2(f)(iii), (iv), (v), (vi), (vii), or (viii), it is necessary so to do, make an order directing that such person detained;

(3) When any order made is under Sub-section (2), the District Magistrate or Additional District Magistrate making the order shall forthwith report the fact to the Government. Together with the grounds on which the order has been made and such other particulars as, in his opinion, have a bearing on the matter, and no such order shall remain in force for more than thirty days after the making thereof unless in the meantime it has approved by the government.

\section{SECTION 8: COMMUNICATION OF GROUNDS OF ORDER}

International Journal of Educational Studies Vol. 1, No. 2, pp. 26-70

2018

DOI: 10.53935/2641-533x.v1i2.19

Corresponding Author: Abdul Hamid

Email: mahannan.law@ru.ac.bd Funding: This study received no specific

Funding: This study
financial support.

Article History:
Received: 3 October 2018

Received: 3 October 2018

Accepted: 22 November 2018

Published: 19 December 2018

() 2018 by the authors; licensee Academic

Publishing Group

| 64
(1) In every case where an order has been made under Section 3, the authority making the order shall as soon as may be but subject to the provisions of Sub Section (2), communicate to the person affected thereby the grounds on which the order has been made enable him to make a representation in writing against the order, and it shall be the duty of such authority to inform such person of his right of making such representation and to afford him the earliest opportunity of doing so;

Provided that nothing in this Section shall require the authority to disclose the facts which it considers to be against the public interest to disclose. 
(2) In the case of a detention order, the authority making the order shall inform the person detained under that order of the grounds of his detention at the time he is detained as soon thereafter as is practicable, but not later than fifteen days from the date of detention.

\title{
SECTION 10: REFERENCE TO ADVISORY BOARD
}

In every case where a detention order has been made under this Act, the Government shall, within one hundred and twenty days from the date of detention under the order, place before the Advisory Board constituted under Section 9 the ground on which the order has been made and the representation, if any, made by the person affected by the order.

\section{SECTION 11: PROCEDURE OF ADVISORY BOARD}

(1) The Advisory Board shall, after considering the materials placed before it and calling for such further information as it may deem necessary from the Government or from the person concerned and after affording the person concerned and opportunity of being heard in person, submit its report to the Government within one hundred and seventy days from the date of detention.

\section{APPENDIX IV: RELEVANT PROVISIONS OF THE UNIVERSAL DECLARATION OF HUMAN RIGHTS (UDHR)}

\author{
Article 3 \\ Every one has the right to life, liberty and the security of person. \\ Article 5
}

No one shall be subjected to torture or to cruel, inhuman or degrading treatment or punishment.

Article 9

No one shall be subjected to arbitrary arrest, detention or exile.

\section{Article 10}

Everyone is entitled in full equality to a fair trial and public hearing by an independent and impartial tribunal, in the determination of his rights and obligations and of criminal charge against him.

\section{Article 11}

1. Everyone charged with a penal offence has the right to be presumed innocent until proved guilty according to law in a public trial at which he has had all the guarantees necessary for his defence.

2. No one shall be held guilty of any penal offence on account of any act or omission, which did not constitute a penal offence, under national or international law, at the time when it was committed. Nor shall a heavier penalty be imposed than the one that was applicable at the time the penal offence was committed.

\section{APPENDIX V: RELEVANT PROVISIONS OF THE INTERNATIONAL COVENANT ON CIVIL AND POLITICAL RIGHTS (ICCPR)}

\section{ARTICLE 9: LIBERTY AND SECURITY OF PERSON}

1. Everyone has the right to liberty and security of person. No one shall be subjected to arbitrary arrest or detention. No one shall be deprived of his liberty except on such grounds and in accordance with such procedure as are established by law.

2. Anyone who is arrested shall be informed, at the time of arrest, of the reasons for his arrest and shall be promptly informed of any charges against him.

3. Anyone arrested or detained on a criminal charge shall be brought promptly before a judge or other officer authorised by law to exercise judicial power and shall be entitled to trial within a reasonable time or to release. It shall not be the general rule that persons awaiting trial shall be detained in custody, but release may be subject to guarantees to appear for trial, at any other stage of the judicial proceedings, and, should occasion arise, for execution of the judgement. 
4. Anyone who is deprived of his liberty by arrest or detention shall be entitled to take proceedings before a court, in order that court may decide without delay on the lawfulness of his detention and order his release if the detention is not lawful.

5. Anyone who has been the victim of unlawful arrest or detention shall have an enforceable right to compensation.

\section{ARTICLE 14: PROCEDURAL GUARANTEES IN CRIMINAL TRIAL}

1. All persons shall be equal before the courts and tribunals. In the determination of any criminal charge against him, or of his rights and obligations in a suit at law, everyone shall be entitled to a fair and public hearing by a competent, independent and impartial tribunal established by law. The press and the public may be excluded from all or part of a trial for reasons of morals, public order or national security in a democratic society, or when the interest of the private lives of the parties so requires, or to the extent strictly necessary in the opinion of the court in special circumstances where publicity would prejudice the interests of justice; but any judgement rendered in a criminal case or in a suit at law shall be made public except where the interest of juvenile persons otherwise requires or the proceedings concern matrimonial disputes or the guardianship of children.

2. Everyone charged with a criminal offence shall have the right to be presumed innocent until proved guilty according to law.

3. In the determination of any criminal charge against him, everyone shall be entitled to the following minimum guarantees, in full equality:

a) To be informed promptly and in detail in a language which he understands of the nature and cause of the charge against him;

b) To have adequate time and facilities for the preparation of his defence and to communicate with counsel of his own choosing;

c) To be tried without undue delay;

d) To be tried in his presence, and to defend himself in person or through legal assistance of his own choosing; to be informed, if he does not have legal assistance, of this right; and to have legal assistance, assigned to him, in any case where the interests of justice so require, and without payment by him in any such case if he does not have sufficient means to pay for it;

e) To examine, or have examined, the witness against him and to obtain the attendance and examination of witnesses on his behalf under the same conditions as witnesses against him;

f) To have the assistance of an interpreter if he cannot understand or speak the language used in court;

g) Not to be compelled to testify against himself or to confess guilt.

4. In the case of juvenile persons, the procedure shall be such as will take account of their age and the desirability of promoting their rehabilitation.

5. Everyone convicted of a crime shall have the right to his conviction and sentence being reviewed by a higher tribunal according to law.

6. When a person has by a final decision been convicted of a criminal offence and when subsequently his conviction has been reversed or he has been pardoned on the ground that a new or newly discovered fact shows conclusively that there has been a miscarriage of justice, the person who has suffered punishment a s a result of such conviction shall be compensated according to law, unless it is proved that the non-disclosure of the unknown fact in time is wholly or partly attributable to him.

7. No one shall be liable to be tried or punished again for an offence for which ha has already been convicted or acquitted in accordance with the law and penal procedure of each country.

International Journal of Educational Studies Vol. 1, No. 2, pp. 26-70

DOI: $10.53935 / 2641-533 x . v 1 i 2.19$

Corresponding Author: Abdul Hamid

Email: mahannan.law@ru.ac.bd Funding: This study received no specific financial support.

Article History:

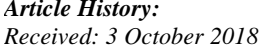

Revised: 29 October 2018

Accepted: 22 November 2018

Published: 19 December 2018

(C) 2018 by the authors; licensee Academic

Publishing Group

| 66 
APPENDIX VI: A LIST OF DRESS FOR THE WOMEN PRISONERS

RULE 1159 OF THE BENGAL JAIL CODE

All prisoners in Division III sentenced to rigorous imprisonment shall be furnished, on admission, with the following jail equipment:

\section{Female prisoners}

\begin{tabular}{l}
\hline 2 cotton chemises or kurtas \\
\hline 10 yards of cotton cloth 42 inches wide \\
\hline 2 gumchas \\
\hline 1 blanket coat \\
\hline$\frac{\text { tatputtee for bedding }}{1 \text { blankets }}$ \\
\hline 1 aluminium cup \\
\hline A square $(2 \mathrm{ft} . \times 2 \mathrm{ft}$.$) of coarse gunny or matting$ \\
\hline 1 comb
\end{tabular}

\section{RULE 1165 OF THE BENGAL JAIL CODE}

Convicted prisoners in Division II sentenced to rigorous imprisonment shall be furnished with the following jail equipment:

a) For the hot weather

Accustomed to European mode of living

\begin{tabular}{|c|c|c|c|}
\hline Cotton skirts & 2 & Saries (pairs) & 2 \\
\hline Cotton blouses & 2 & Cotton blouses & 2 \\
\hline Cotton shirts & 2 & Chemise or shirts & 2 \\
\hline Cotton drawers (pairs) & 2 & Drawers (pairs) & 2 \\
\hline Cotton stockings (pairs) & 2 & Stockings (pairs) & 2 \\
\hline Garters (pair) & 1 & Garters (pair) & 1 \\
\hline Leather belt & 1 & & \\
\hline Cap & 1 & & \\
\hline Sola topi & 1 & & \\
\hline
\end{tabular}

b) For the cold weather and rains

Accustomed to European mode of living

Accustomed to Indian mode of living

\begin{tabular}{|c|c|c|c|}
\hline Cotton skirt & 1 & Saries (pairs) & 3 \\
\hline Cotton blouse & 1 & Cotton blouse & 1 \\
\hline Woollen shirt & 1 & Woollen blouse & 1 \\
\hline Woollen blouse & 1 & Flannel shirts or chemise & 2 \\
\hline Flannel shirts & 2 & Cotton drawers (pairs) & 2 \\
\hline Cotton drawers (pairs) & 2 & Stockings (pairs) & 2 \\
\hline Cotton stockings (pairs) & 2 & Garters (pair) & 1 \\
\hline
\end{tabular}

\section{Accustomed to Indian mode of living}

International Journal of Educational Studies Vol. 1, No. 2, pp. 26-70 


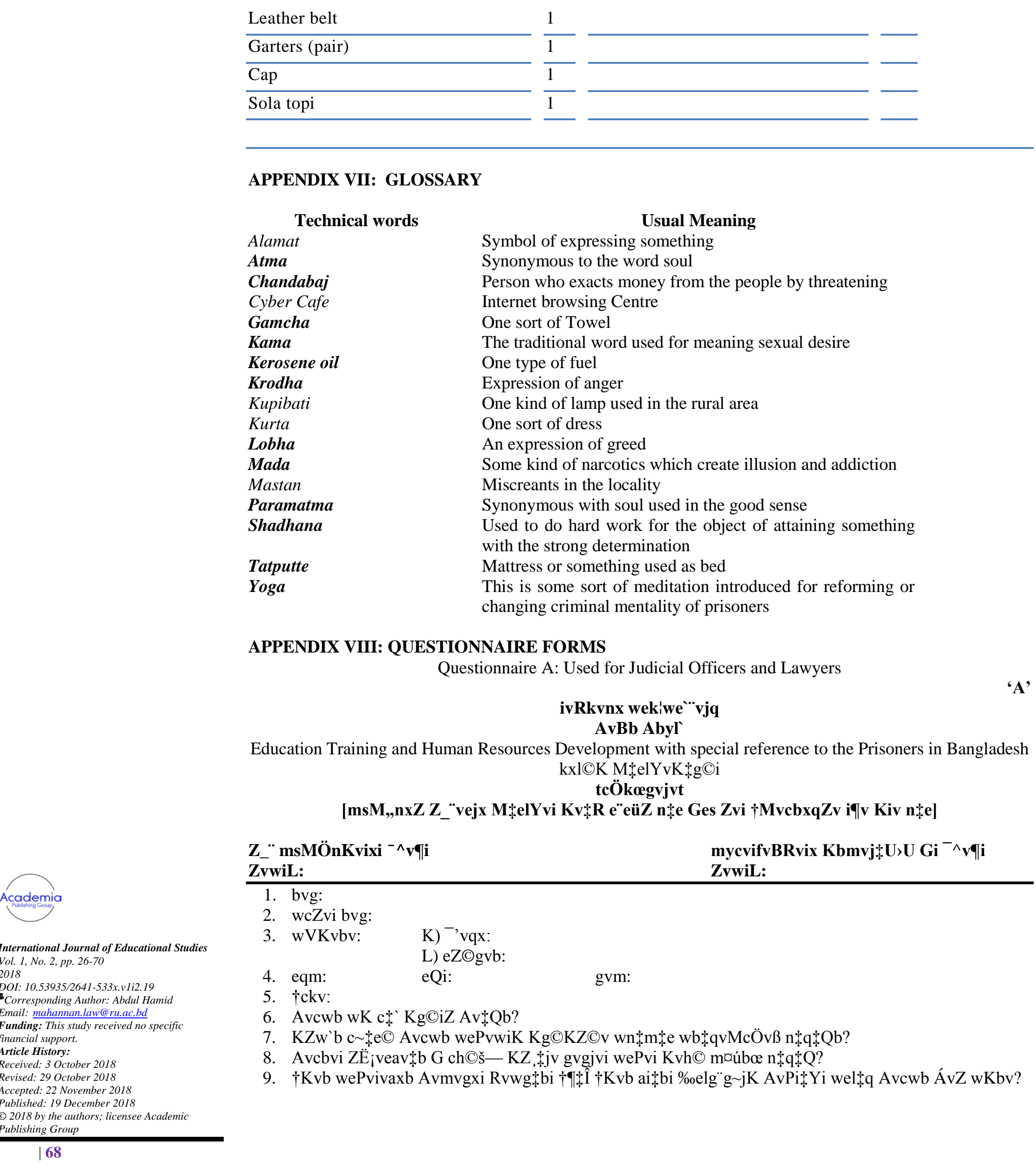




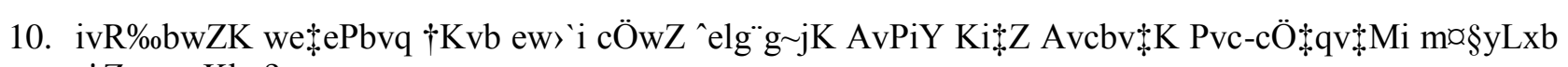
$n \ddagger Z$ nq wKbv?

11. †dŠR`vix Kvh@wewai 54 aviv Abyhvqx m†`ng jK AvUK Ges 164 aviv Abyhvqx cywjk KZC,,K

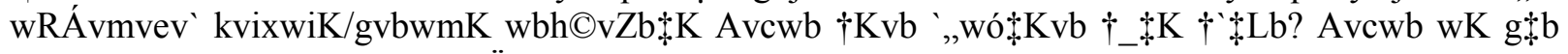

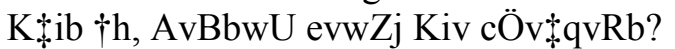

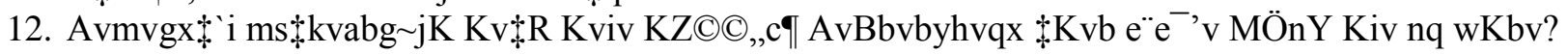

\title{
Questionnaire B: Used for Police Officer or Jail Officer
}

$$
-\wedge \mathbf{v} \llbracket \mathbf{i}
$$

\section{ivRkvnx wekiwe ${ }^{\cdots}$ vju}

\author{
AvBb Abyl
}

Education Training and Human Resources Development with special reference to the Prisoners in Bangladesh $\mathrm{kxl} C \mathrm{~K} \mathrm{M}+\mathrm{elYvK}+\mathrm{g} \odot \mathrm{i}$

$$
\text { tcÖkogvjvt }
$$

[msM,nxZ Z_vejx MłelYvi KvłR e“eüZ n†e Ges Zvi †MvcbxqZv iqv Kiv n†e]

\section{$Z_{-}{ }_{-} \operatorname{msMÖnKvixi}{ }^{-\wedge} \mathbf{v} \rrbracket i$}

ZvwiL:

1. bvg:

2. wcZvi bvg:

3. wVKvbv:

4. eqm:

5. †ckv:

6. Avcwb cywjk wKsev Kviv Kg@KZCv nłj wK cł Kg@iZ AvłQb?

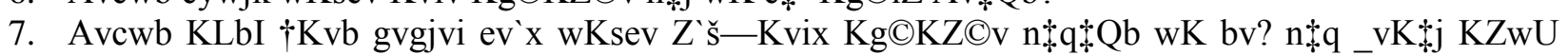
gvgjvi ev`x wKsev Z`š-Kvix Kg@KZ@v nłqłQb? gvgjvi djvdj wK nłqwQj?

8. mgv

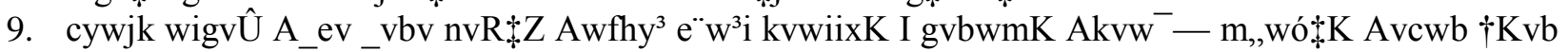
„wó $+K v b \dagger+\$ \bar{K} \dagger \mathrm{L}+\mathrm{Qb}$ ?

10. wePvivaxb $\dagger \mathrm{Kvb}$ Avmvgxi gvbevwaKvi msi $\uparrow \mathrm{Y}$ AvBb cÖłqvMKvix ms ${ }^{-}$'vi $\mathrm{f} \sim$ wgKv $\dagger \mathrm{Kgb}$ nIqv cÖ qvRb e $\ddagger j$ Avcwb głb K $₫$ ib?

11. wbeZCbg jK AvUK $₫ K$ Avcwb KZUzKz AvBbvbyM I gvbweK głb K $₫ i b$ ?

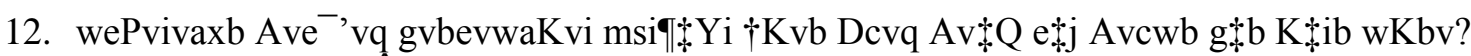

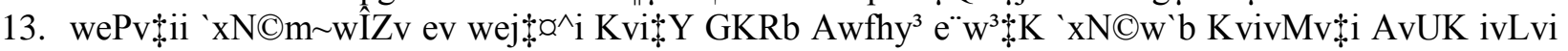
$\dagger \mathrm{Kvb}$ AvBbMZ wfwË Av Q e $\ddagger j$ Avcwb K†b K†ib wKbv?

14. Kviv Af š-

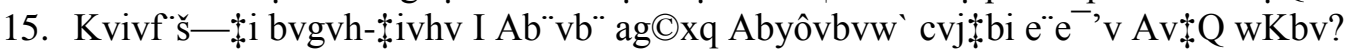

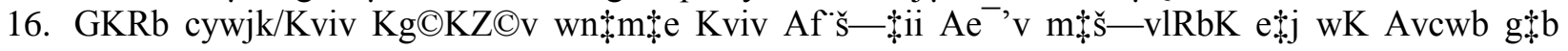
$\mathrm{K}+\mathrm{ib}$ ?
K) n“uv
L) bv
M) $g \check{s}-e^{*} \dagger b B$

mycvifvBRvix KbmvjłU>U Gi ${ }^{-\wedge} \vee q i$

ZvwiL:
International Journal of Educational Studies Vol. 1, No. 2, pp. 26-70

2018

DOI: 10.53935/2641-533x.v1i2.19

Corresponding Author: Abdul Hamid

Email: mahannanlaw@ru.acbd

Funding: This study received no specific

financial support.

Article History:

Received: 3 October 2018

Revised: 29 October 2018

Accepted: 22 November 2018

Published: 19 December 2018

(C) 2018 by the authors; licensee Academic Publishing Group

| 69

B' 
Questionnaire C: Used for Victims or Prisoners

ivRkvnx wekiwe“"vjq

\section{AvBb Abyl}

Education Training and Human Resources Development with special reference to the Prisoners in Bangladesh kxl@K MłelYvKłg@i

tcÖkœgvjvt

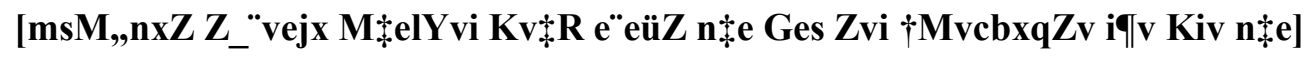

$\mathrm{Z}_{-}{ }^{-*} \operatorname{msMÖnKvixi}^{-\wedge} \mathbf{v} \| \mathrm{i}$

ZvwiL:

mycvifvBRvix KbmvjłU〉U Gi ${ }^{-\wedge} \vee q i$

1. bvg:

2. wcZvi bvg:

3. wVKvbv:

ZvwiL:

4. eqm:

K)
L) eZCgvb:
eQi:

K) ${ }^{-,}$vqx:

5. †ckv:

gvm:

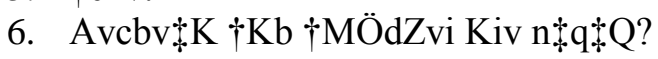

7. wePvivaxb gvgjv $\uparrow \mathrm{Kvb}$ ch@v $₫ \mathrm{q} A v \dagger \mathrm{Q}$ ?

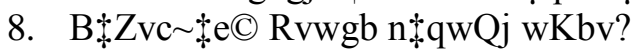

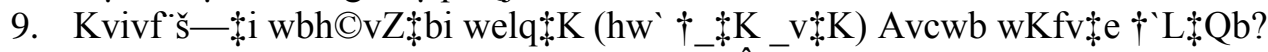

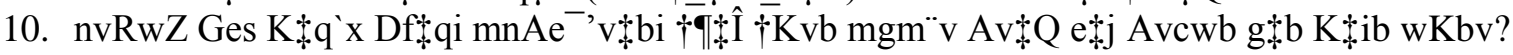

11. Kvivf $\breve{s}$ -

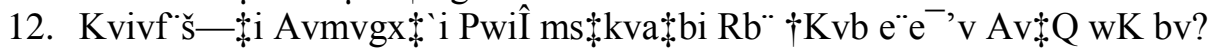

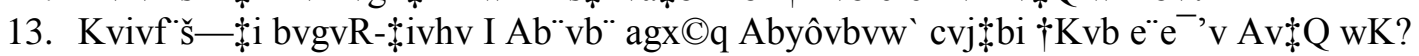

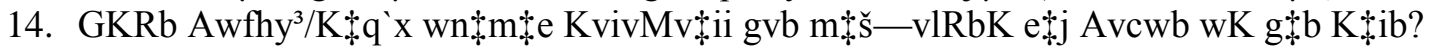
K) n"uv
L) bv
M) $g \check{s}-e^{*} \dagger b B$ 